Portland State University

PDXScholar

5-1-1969

\title{
Evaluation of the role of neighborhood health coordinators in a comprehensive neighborhood health services project
}

\author{
Sharron Faye Easley \\ Portland State University \\ John Collins Flanagan \\ Portland State University \\ Janet Fredricksen \\ Portland State University \\ Linda Janice Johnson \\ Portland State University \\ Beatrice Hays Young \\ Portland State University
}

Follow this and additional works at: https://pdxscholar.library.pdx.edu/open_access_etds

Let us know how access to this document benefits you.

\section{Recommended Citation}

Easley, Sharron Faye; Flanagan, John Collins; Fredricksen, Janet; Johnson, Linda Janice; and Young, Beatrice Hays, "Evaluation of the role of neighborhood health coordinators in a comprehensive neighborhood health services project" (1969). Dissertations and Theses. Paper 890.

https://doi.org/10.15760/etd.890

This Thesis is brought to you for free and open access. It has been accepted for inclusion in Dissertations and Theses by an authorized administrator of PDXScholar. Please contact us if we can make this document more accessible: pdxscholar@pdx.edu. 
AN ABSTRACT OF THE GROUP PROJECT of Sharron Faye Easley, John Collins Flanagan, Janet Fredricksen, Linda Janice Johnson and Beatrice Hays Young for the Master of Social Work presented May 22, 1969.

Title: Evaluation of the Role of Neighborhood Health Coordinators in a Comprehensive Neighborhood Health Services Project.

APPROVED BY MEMBERS OF THE GROUP PROJECT COMMITTEE:

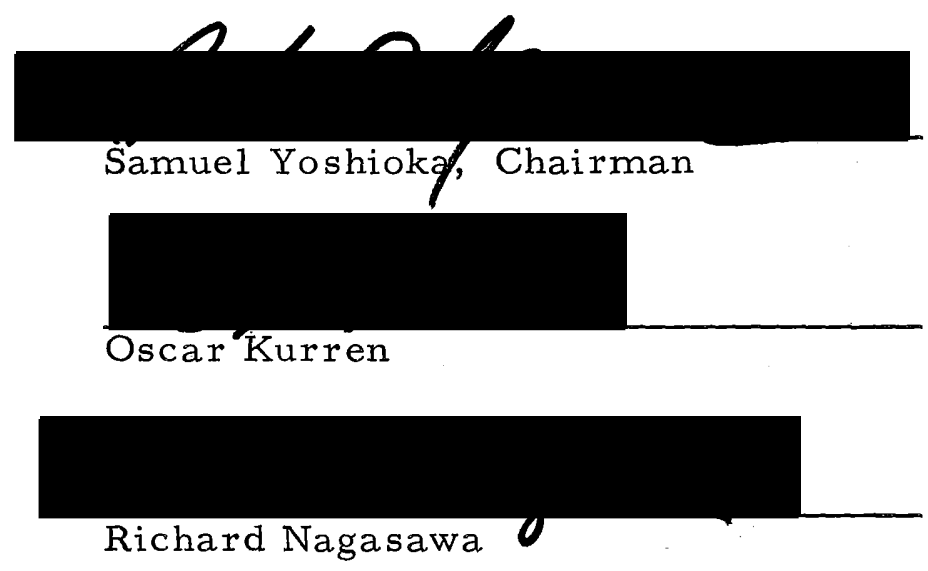

This study evaluates the role of the Neighborhood Health Coordinators (NHC's) within Kaiser Foundation's Comprehensive Neighborhood Health Services (CNHS) Project. This project was established in September, 1967, under the provisions of the 1966 amendments to the Economic Opportunity Act, to provide and make readily available comprehensive medical care to low-income 
persons. In compliance with the stipulations of this Act, persons who reside in target areas, designated as depressed neighborhoods, were hired to serve as NHC's. These indigenous non-professionals serve as links or "gatekeepers" between the low-income persons enrolled in this program, and the Kaiser medical care facilities which include the hospital-clinic and three neighborhood health clinics.

The NHC's were to enroll these low-income families in the program, and assist them in obtaining appropriate health services. In addition to the se primary responsibilities, the NHC's were to refer their clients to community resources whenever necessary.

The impact of the NHC's contact with families enrolled in the program was evaluated on the basis of two major indices: utilization of total medical care services and four specific areas of preventive health care.

The findings of this study support the underlying assumption upon which the NHC's were hired and trained; that is, they are effective in increasing the total utilization of out-patient medical services and utilization of specific preventive health services by families with whom they have the most personal contact.

In a secondary analysis, characteristics related to several CNHS Project objectives, attitudinal scales and socio-demographic characteristics are examined to determine their relationship to the 
staff's perception of an "ideal" NHC. This analysis shows that aptitude in interpersonal relationships and personal growth are two characteristics highly associated with rank. Several attitudinal scales, especially powerlessness and dogmatism, are positively as sociated with rank. Measures of knowledge in the areas of health and medical care programs have a low or negative as sociation with rank. This study does not make an exhaustive investigation of characteristics which may be associated with rank; therefore, other variables considered by the administrative staff in their evaluation of an "ideal" NHC may not have been measured. 
EVALUATION OF THE ROLE OF NEIGHBORHOOD HEALTH

COORDINATORS IN A COMPREHENSIVE NEIGHBORHOOD

HEALTH SERVICES PROJECT

by

SHARRON FAYE EASLEY

JOHN COLLINS FLANAGAN

JANET FREDRICKSEN

LINDA JANICE JOHNSON

BEATRICE HAYS YOUNG

A group project submitted in partial fulfillment of the requirements for the degree of

MASTER OF SOCIAL WORK

Portland State University

1969 
TO THE OFFICE OF GRADUATE STUDIES:

The members of the Committee approve the Group

Project of Sharron Faye Easley, John Collins Flanagan,

Janet Fredricksen, Linda Janice Johnson and Beatrice Hays

Young presented May, 22, 1969.

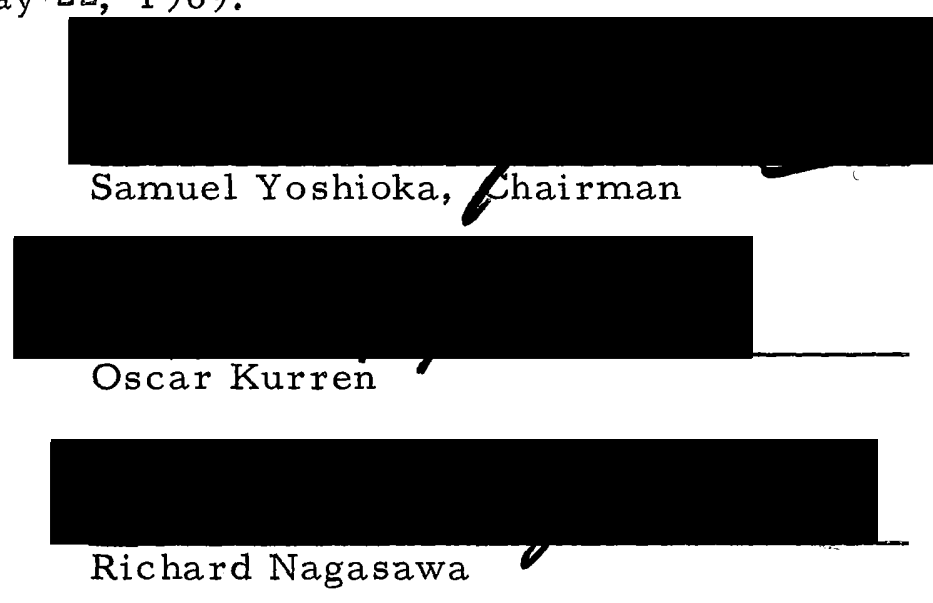

APPROVED:

Daniel E. Jennings, Acting Dean, School of Social Work

Gavid R. Malcolm, Acting Dean of Graduate-Studies

May 22, 1969 


\section{A CKNOW LEDGMENTS}

A number of persons contributed, either directly or indirectly, to the writing of this group project report. We want to give special thanks to Samuel S. Yoshioka, our advisor and Associate Director of the Health Services Research Center, whose guidance, patience, and unwaivering optimism helped us overcome what at times seemed to be insurmountable obstacles to the completion of this project. In addition we wish to thank the other members of our group project committee, Oscar Kurren and Richard Nagasawa, for reading and making recommendations for this study.

We are also indebted to the following members of the Health Services Research Center staff: to Theodore J. Colombo, Associate Director and Project Administrator; Sol Peck, Project Social Worker; and Angie M. Richardson, Training Coordinator, for their cooperation in making information and ideas available to us; to Nancy Hunt, Administrative Assistant, for her able guidance and assistance in data collection and for repeated explanations of the computer outputs; to Harvey Solomon, Research Assistant, for running numerous statistical analyses on our data; and finally to the Neighborhood Health Coordinators themselves for their cooperation. 
Our thanks go to those groups and individuals who cooperated in the development of the test instruments.

Finally, for their patient understanding, encouragement and support during our moments of frustration we thank the members of our respective families, with a special thanks to Pauline Flanagan and Cheryl Brooks who so generously gave their own time typing repeated rough drafts of various parts of this report.

Sharron Faye Easley John Collins Flanagan Janet Fredricksen Linda Janice Johnson Beatrice Hays Young 
TABLE OF CONTENTS

PAGE

ACKNOWLEDGMENTS . . . . . . . . . . . . . iii

LIST OF TABLES .................. viii

\section{CHAPTER}

I INTRODUCTION .............. 1

II SETTING AND BACKGROUND ........ . 3

Kaiser Foundation Setting . . . . . . 3

OEO Background ............ . . 4

Kaiser Foundation Comprehensive

Neighborhood Health Services Project. 5

Description of the Neighborhood Health

Coordinators........... 7

III OPERATIONALIZATION OF THE OBJECTIVES OF THE COMPREHENSIVE NEIGHBOR HOOD HEALTH SERVICES PROJECT . . . 10

Objectives of the Comprehensive

Neighborhood Health Services Project. 10

Rationale for the Comprehensive

Neighborhood Health Services Project. 12

Objectives of the Research Study..... . 15

IV EVALUATIVE RESEARCH : . . . . . . 17 
Definition of Evaluative Research . . . . 18

Models for Evaluative Research ...... 19

V METHODOLOGY ............ 25

Classical Experimental Design....... 25

Research Design . . . . . . . . . . . 28

Secondary Analysis.......... 30

Development of Questionnaires. . . . . . 31

Scales............... . . 34

Statistics . . . . . . . . . . 37

Summary ............. . 37

VI ANALYSIS OF THE DATA. . . . . . . . . 40

Effectiveness of NHC's as "Gatekeepers":

The Primary Analysis... . . . . 40

Total Utilization of Out-patient

Services

Utilization of Preventive Services

Interpretation of the Utilization Data

Characteristics of an "Ideal" Neighborhood

Health Coordinator: The Secondary

Analysis ............ 53

VII SUMMARY AND CONCLUSIONS. . . . . . . 69

Summary .. . . . . . . . . 69

Conclusions.............. 70

Recommendations........... . 72

A SELECTED BIBLIOGRAPHY . . . . . . . . . . . . 74 
APPENDICES

A Sample Monthly and Daily Contact Forms. . . . 83

B California Relative Value Studies Codes as Revised by Kaiser Foundation . . . . . 86

C Sample Rating Form . . . . . . . . . 87

D Test Scales................ . . 88

E Percentage Distributions of Scores on Rating Questionnaire Questions by Rank of Neighborhood Health Coordinators . . . . 


\section{LIST OF TABLES}

TABLE

PAGE

I Comparisons Between Time Periods on Monthly

Rate of Utilization of Out-patient Services

Per 100 Persons by Two Groups Differing in Contact...............

II Comparisons Between Time Periods on Pro-

portion of Utilization by Preventive Health

Care Service for the "Most Personal

Contact" Group ..............

III Comparisons Between Time Periods on Pro-

portion of Utilization by Preventive Health

Care Service for the "No Personal Contact"

Group ................ .

IV Comparisons Between Groups (Differing in

Contact) on Monthly Rate of Utilization of

Out-patient Services Per 100 Persons by

Time Period. . . . . . . . . . . . 
V Comparisons Between Groups (Differing in Contact) on Proportion of Utilization by Preventive Health Care Service for the First Nine Months of the First Project Year ...........

VI Comparisons Between Groups (Differing in Contact) on Proportion of Utilization by Preventive Health Care Service for the Last Three Months of the First Project Year....... 50

VII Number Distributions of Coordinators Considered by One or More of the Project Staff to be Employable in the Regular Labor Market by Area of Employability . . . . . . . . .

VIII Percentage Distributions of Scores on the

California Health Behavior Inventory--High

School Level by Rank of Neighborhood Health

Coordinators................

IX Percentage Distributions of Scores on the

California Health Behavior Inventory--

College Level by Rank of Neighborhood

Health Coordinators ............ 
X Percentage Distributions of Scores on the General

Health Questionnaire by Rank of Neighborhood

Health Coordinators ........... . 60

XI Percentage Distributions of Scores on the Kaiser

Health Plan and Programs Questionnaire by

Rank of Neighborhood Health Coordinators...

XII Percentage Distributions of Scores on the

Community Resources Questionnaire by Rank

of Neighborhood Health Coordinators . . . . .

XIII Percentage Distributions of Scores on the

Occupational Primacy Scale by Rank of

Neighborhood Health Coordinators . . . . . .

XIV Percentage Distributions of Scores on the Anomia

Scale by Rank of Neighborhood Health

Coordinators............... . . 64

XV Percentage Distributions of Scores on the Power-

lessness Scale by Rank of Neighborhood

Health Coordinators .......... 65

XVI Percentage Distributions of Scores on a Shortened

Version of the Rokeach Dogmatism Scale by

Rank of Neighborhood Health Coordinators . . 66 
XVII Percentage Distributions on Age by Rank of

Neighborhood Health Coordinators. . . . . 66

XVIII Percentage Distributions on Level of Education

by Rank of Neighborhood Health Coordinators .

XIX Percentage Distributions of Scores on Rating

Questionnaire Question Number One by

Rank of Neighborhood Health Coordinators ..

XX Percentage Distributions of. Scores on Rating

Questionnaire Question Number Two by

Rank of Neighborhood Health Coordinators . . 100

XXI Percentage Distributions of Scores on Rating

Questionnaire Question Number Three by

Rank of Neighborhood Health Coordinators . . 100

XXII Percentage Distributions of Scores on Rating

Questionnaire Question Number Four by

Rank of Neighborhood Health Coordinators . . 101

XXIII Percentage Distributions of Scores on Rating

Questionnaire Question Number Five by

Rank of Neighborhood Health Coordinators . . 101

XXIV Percentage Distributions of Scores on Rating

Questionnaire Question Number Six by

Rank of Neighborhood Health Coordinators . . 102 
XXV Percentage Distributions of Scores on Rating

Questionnaire Question Number Seven by

Rank of Neighborhood Health Coordinators. . 102 


\section{CHAPTER I}

\section{INT RODUCTION}

This study focuses on the role of the Neighborhood Health Coordinators in Kaiser Foundation's Comprehensive Neighborhood Health Services Project for low-income families. The Comprehensive Neighborhood Health Services Project (henceforth referred to as the CNHS Project) is financed by the Office of Economic Opportunity (OEO) and was made possible by the Economic Opportunity Act of

1964 and its amendments, particularly that of 1966 which pertains to Comprehensive Health Services.

Neighborhood Health Coordinators are indigenous non-professionals residing in low-income areas who act as links between lowincome families of their respective neighborhoods and the Kaiser medical care facilities. They are expected to assist these families to utilize needed health services, particularly those which are preventive in nature. The primary focus of this study is to evaluate their effectiveness in this role. Secondarily, this study will attempt to identify characteristics associated with an "ideal" Neighborhood Health Coordinator as perceived by the administrative staff of the Project. 
In addition to its evaluative purposes, there were several other considerations underlying the decision to undertake this study. The members of the research group selected this study because of an interest in, and desire for, experience in program evaluation. Most graduates obtaining advanced degrees in Social Work eventually find themselves with administrative responsibilities. It was felt that experience in program evaluation would be an invaluable asset. Another consideration was that findings of this study may be of value both to administrators of comprehensive health services programs and to the Office of Economic Opportunity through which these programs are financed.

The following chapter discusses the Kaiser Foundation Medical Care Program, the background of the Office of Economic Opportu-nity, and how the broader goals of these larger organizations influence the local CNHS Project. A discussion of the CNHS Project's objectives and how these objectives are operationalized are covered in Chapter III. Chapter IV presents two predominant models used in evaluative research followed by a discussion of the methodology utilized in this study in Chapter V. The data are presented and analyzed in Chapter VI. Summary, conclusions and recommendations are then made in the final chapter. 


\section{CHAPTER II}

\section{SETTING AND BACKGROUND}

\section{KAISER FOUNDATION SETTING}

The Kaiser Foundation Medical Care Program provides comprehensive family medical care for about $1,700,000$ subscribers and dependents throughout the Pacific Coast States and Hawaii. ${ }^{1}$ It was originally initiated to provide medical service for workmen on remote construction projects during the $1930^{\prime} \mathrm{s}$, and in 1945 was expanded to serve a broad based community wide population. Unlike many insur ance plans, the Kaiser program assumes the responsibility for or ganizing and providing health care services for its members. These responsibilities are discharged through the incorporation of five basic principles: voluntary enrollment, the organization of health services around group medical practice and integrated care facilities, prepayment for services, comprehensive benefits, and preventive medical care. $^{2}$

${ }^{1}$ Kaiser Foundation Medical Care Program Report, 1967 (Oakland, California: Public Affairs Department, Foundation Health Plan, Inc., 19.68), p. 2.

2 Kaiser Foundation Medical Care Program Report, 1960 (Oakland, California: Public Affairs Department, Foundation Health Plan, Inc., 1961), pp. 5-13. 
In the Portland area, 110,000 people, about 15 per cent of the total metropolitan population, are being served by the Kaiser Foundation Medical Care Program. The Medical Care Program is centered at Bess Kaiser Hospital, a 230-bed facility located in North Portland. Physicians' services are provided for health plan members at a clinic integrated into the hospital complex and at three neighborhood clinics located in Northeast and Southeast Portland, Oregon and in Vancouver, Washington. A partnership of physicians consisting of 85 board-certified or board-eligible specialists in all major fields of medicine, including psychiatry, staff the clinics and hospitals. 3

\section{OEO BACKGROUND}

The OEO Act of 1964 was enacted "to mobilize the human and financial resources of the nation to combat poverty in the United States. "1 4 This Act contends that, in order for the United States to achieve its full economic and social potential, every individual must be given the opportunity to participate in the workings of society and to contribute to the full extent of his capabilities. This potential is to be realized through making available to everyone, education,

3

Theodore J. Colombo, Ernest W. Saward, and Merwyn R. Greenlick. "The Integration of an OEO Health Program into a Prepaid Comprehensive Group Practice Plan, "Unpublished report to the American Public Health As sociation, Detroit, November 13, 19.68, p. 2.

${ }^{4}$ Public Law 88-452. "Economic Opportunity Act of 1964." August 20, 1964, Section 2, p. 503. 
training, employment and the possibility of living in decency and dignity. 5

A 1966 amendment to the OEO Act provided federal funds to as sist local areas in establishing health service centers for low-income people. This amendment stipulated that centers should operate in low-income neighborhoods in order to make comprehensive medical and dental care more readily available to the people. Projects were also directed to include the participation of neighborhood residents, to have competent medical supervision, and to utilize existing agencies and resources as much as possible. ${ }^{6}$ It was stipulated that emphasis should be placed on establishing programs in poverty areas where there is a marked inadequacy of health services. The following services were to be offered: preventive-medical, diagnosis, treatment, rehabilitation, mental health, dental, and follow-up. 7

\section{KAISER FOUNDATION COMPREHENSIVE NEIGHBORHOOD HEALTH SER VICES PROJECT}

In June of 1967, Kaiser Foundation Hospital's Medical Care Research Unit received funds to establish a comprehensive medical

${ }^{5}$ Ibid.

${ }^{6}$ Office of General Counsel, Office of Economic Opportunity. Narrative Summary of the Economic Opportunity Amendments of 1966. (Washington: U.S. Government Printing Office, 1967), p. 6

7 Public Law 89-794. "Comprehensive Health Services Programs." November 8, 1966, Section $211-2$, p. 1463. 
care program (the CNHS Project) under the auspices of the OEO.

The program was facilitated by the fact that the Kaiser Hospital complex and three clinics were located in the identified poverty areas.

Two of Kaiser's basic principles--prepaid medical care and use of integrated facilities--also met the requirements of the OEO Act.

The Portland Metropolitan Steering Committee designated five target areas as "pockets of poverty. "8 By mid-July, 1967, an advisory committee was formed which included two neighborhood representatives from each of the five target areas. It was felt that greater participation of the residents would be enhanced through this neighborhood advisory committee. Through a joint effort of this advisory board and the Kaiser staff, sixteen low-income persons -fifteen women and one man--were initially hired from the target areas to serve as Neighborhood Health Coordinators. It was felt that these Coordinators would be able to encourage participation in the program and circumvent resistance of the neighborhood residents due to fear of the unknown. In addition, they would have the advantage of greater knowledge of the community and the families they serve. 9

${ }^{8}$ These areas include Albina in North Portland and Brooklyn, Buckman, Richmond and Sunnyside in Southeast Portland.

${ }^{9}$ Kaiser Foundation Research Institute (Delegate Agency). "Comprehensive Neighborhood Health Services Project: Progress Report and Work Plan for Program Year 2." Office of Economic Opportunity-Community Action Program Grant \#CG-ORE-67-8392, Portland, Oregon, 1968, pp. 3-5 
In August, 1967, a Social Worker and Project Administrator were hired to administrate and train the NHC's. Formal training of the Coordinators took place during their initial six weeks of employment. In September, 1967, these Coordinators began recruiting families from their neighborhoods to take part in Kaiser's CNHS Project. Of the 4,000 families eligible for participation under the definition of poverty--income level, size of family, and place of residence $-1,200$ were initially enrolled in this program. Priority was given to large families with small children and to families with known acute health problems but with no existing medical care source. 10

A second group of Neighborhood Health Coordinators--fifteen women and one man--were hired and trained in May, 1968. At this time it was proposed that the geographical area and number of persons being served be expanded. Due to an administrative decision, these plans were delayed, and only two of the second group of Coordinators were assigned caseloads. At the time of this study, there were fifteen active caseloads.

\section{DESCRIPTION OF THE NEIGHBORHOOD HEALTH COORDINATORS}

Available information about the Coordinators suggests that the first group of sixteen NHC's come from a variety of backgrounds,

$$
10 \text { Ibid., p. } 4 .
$$


but a number of generalizations may be made. The fact that nine NHC's are Negro and seven are Caucasian reflects the racial composition of the target area in which they reside. A composite NHC may be described as a 37-year-old Negro woman with just under a twelfth grade education, rearing three minor children alone. Prior work experience, which averaged about four years, was most likely to have been as either a waitress or housekeeper. Some NHC's, however, had previous experience working as aides in other OEO funded projects (six of sixteen had this kind of experience). Although she may have had some business training, it is unlikely that she had done much actual office work.

Ages of the NHC's ranged from 21 to 50; educational levels varied from ninth grade through three years of college, and length of previous employment was from five months to fifteen years. All had been either in the labor market or in school within the year and onehalf prior to their employment with the Kaiser CNHS Project. Fifty per cent were employed when they made application for this job.

Similar features were noted in the second group of Coordinators, but there were some distinct differences between the two groups. Because this group represented, and was expected to serve in, other areas of Portland where the racial composition was predominantly white, only four of the sixteen were black. Age range was similar, (22 to 58, average age about 38 years) but the 
education level was generally higher (tenth grade through four years of college, average about thirteen years). The employment pattern was also different. Only four were working when they applied for the Coordinator job and several had not worked in the past five years. Only two had worked in other OEO programs and it was more likely that these Coordinators had previously had office work experience. Apart from meeting the requirements of poverty, and being a resident of the area where services were being extended, it was not apparent that any particular type of individual was being sought at the time of hiring. Some had demonstrated leadership abilities in other OEO programs, or in private enterprise. In others, however, this skill was not readily apparent. 


\section{CHAPTER III}

\section{OPERATIONALIZATION OF THE OBJECTIVES OF THE COMPREHENSIVE NEIGHBORHOOD HEALTH SERVICES PROJECT}

\section{OBJECTIVES OF THE COMPREHENSIVE NEIGHBORHOOD HEALTH SERVICES PROJECT}

The underlying assumption for the establishment of the Comprehensive Neighborhood Health Services Project is that, in this "land of plenty" where medical technology and practices are the most advanced in the world, the re exist inequalities in the availability of medical care. ${ }^{1}$ In order to ameliorate this situation, programs such as the Kaiser CNHS Project have been established to bring about greater participation in the medical care system by that segment of the population who have been deprived of adequate medical services. The unique features of the Kaiser Medical Care Program were

${ }^{1}$ For further discussion on this subject see Otto Kerner, et al., Report of the National Advisory Commission on Civil Disorder (New York: E. P. Dutton and Co., Inc., 1968), p. 269; Elijah L. White, "Age and Income Differentials in Selected Aspects of Morbidity, Disability and Utilization of Health Services, "Inquiry, V, No. 1 (March, 1968), pp. 18-30; and August LaRocco (ed.). Poverty and Health in the United States-A Bibliography with Abstract (New York: Medical and Health Research Assn., 1967). 
compatible with the goals of OEO and easily adapted to the requirements of the 1966 CNHS Programs Amendment. Program objectives of the CNHS Project administrators include the following:

1. To provide high quality, comprehensive, coordinated and continuous family health care services to a low-income population within the framework of the ongoing, prepaid, group practice medical care plan.

2. To educate the population to fully and appropriately utilize the services of this health care system. Lowincome neighborhood residents will be trained as Health Aides and will help integrate the participants into the system through the use of health education techniques and generally supportive services. 2

From the standpoint of the project administrators, the NHC's are the means through which the Project's objectives can be accomplished. The assumption here is that the NHC's serve as mediators between low-income families in their neighborhoods and the Kaiser Medical Care facilities. Specifically, the NHC's primary function is to encourage low-income families to develop appropriate patterns of health care seeking behavior which include making use of preventive health care services. ${ }^{3}$ The NHC's first recruited eligible families

${ }^{2}$ Kaiser Foundation Research Institute. (Delegate Agency). "Comprehensive Neighborhood Health Services Project, " Narrative for the Proposal for Office of Economic Opportunity--Community Action Program Grant \#CG-ORE-67-8392, Portland, Oxegon, 1967. pp, 4-5.

3 Kaiser Foundation Research Institute. (Delegate Agency). "Comprehensive "Neighborhood Health Services Project, Narrative for Quarterly Report, October-December, 1967." Office of Economic Opportunity--Community Action Program Grant \#CG-ORE67-8392, Portland, Oregon, 1968. p. 6. 
for the program. Their ongoing duties are to help these families make and keep appointments, to deal with barriers such as transportation and childcare problems, and to explain existing services to the participants. 4

\section{RATIONALE FOR THE COMPREHENSIVE NEIGHBORHOOD HEALTH SERVICES PROJECT}

Underlying the CNHS Project's objectives is the as sumption that indigenous non-professionals can be utilized to function as the links between two social systems. Coming from one social system (a low-income neighborhood) and being hired into another social system (the Kaiser Health Care Program), the NHC's perform the function of linking the two systems.

Systemic linkage has been conceptualized by Charles Loomis and his associates as a "process whereby one or more of the elements of at least two social systems is articulated in such a manner that the two sytems in some ways and on some occasions act as a single unit. $"{ }^{5}$ They go on to state that responsibility for this inter action rests with persons who act as living links between the groups

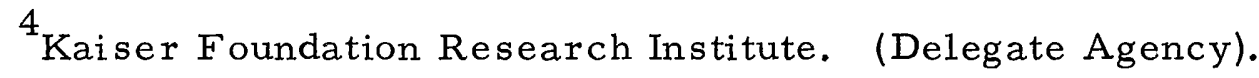
Quarterly Report, op. cit., p. 6.

${ }^{5}$ Charles P. Loomis, Social Systems (Princeton, N. J.: D. Van Nostrand Co., Inc., 1960), p. 32. 
engaged in the exchange. ${ }^{6}$ The linkage of the two systems by the NHC's can be diagramed as follows:

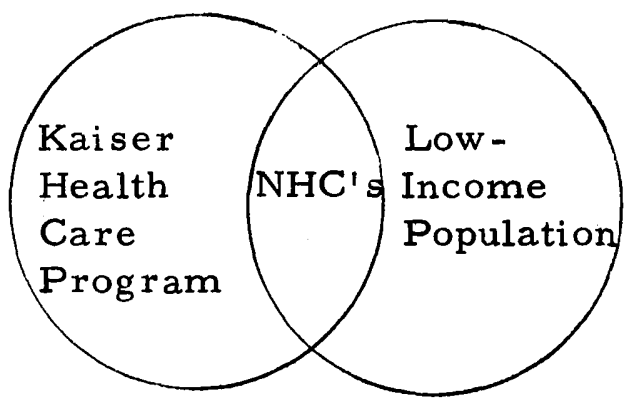

Within any social system, boundary maintenance processes are at work which set limits on the amount of interaction between groups. To counter this, systemic linkage is seen as the process whereby arrangements are made which allow group interdependencies to occur. ${ }^{7}$ Both elements are viewed as being necessary within any given social system.

Without boundary maintenance, social groups would be indistinguishable among a mass of individuals and interaction would be haphazard; without systemic linkage an unthinkable parochialism would deny to groups any form of contact outside of their own boundaries. 8

Relying heavily on Loomis, another sociologist, Norman Kurtz, has attempted to define and describe the role of the persons who act as systemic links between two cultures. He has labeled these persons "gatekeepers" and defines them as, "individuals who have relatively ready access to information and facilities in the

${ }^{6}$ Ibid., p. $33 \quad 7$ Ibid,, pp. 32-33. 8 Ibid. 
community and who are relatively accessible to persons who need links to information and facilities. 19 He studied the informal gatekeeping system of a particular community and came to the conclusion that there are many inefficiencies in the informal process although the gatekeepers are constantly seeking to make their attempts to help more fruitful. He found that each gatekeeper was limited in the number of role contexts in which he was able to operate because he was not aware of many community resources. The requests for help were unevenly distributed among gatekeepers and the result was that people operated as gatekeepers in areas in which they were not adept. $^{10}$

In structuring the Coordinators' jobs, the CNHS Project has attempted to deal with some of the problems described by Kurtz. Instructions were given the NHC's about available community resources as well as about the Kaiser Health Care Program. Their role context is limited primarily to the area of health and medical care, and presumably, some expertise has been gained by the Coordinators in this area. In brief, this project formalizes and institutionalizes the gatekeeping process described by Kurtz.

${ }^{9}$ Norman P. Kurtz, "Gatekeepers in the Process of Acculturation," (Unpublished Ph. D. dissertation, Dept. of Sociology, University of Colorado, 1966), p. 70.

$10_{\text {Ibid. , pp. } 272-275 .}$ 


\section{OBJECTIVES OF THE RESEARCH STUDY}

This study considers the role of the NHC's and their contribution to the fulfillment of the general objectives of the CNHS Project. Specifically, this study investigates whether Coordinators influence utilization of medical care services by, and health care practices among, low-income families. A secondary objective is to determine attributes which may be associated with the administrative staff's perception of an "ideal" NHC.

One would expect that if a Coordinator is effective, the frequency of contact that she has with her assigned families will affect total utilization of out-patient medical care services by these families. The assumption is that the amount of utilization of health services reflects how well persons have been acculturated into the medical care system. The first objective is, therefore, to determine the effect of the NHC's on the total utilization of Kaiser's out-patient medical care services by a sample from the Project population.

A second relationship selected for examination in this study is concerned with determining the NHC's effectiveness in encouraging the families they serve to obtain preventive medical care services -Well Child Care, Pap Smears, Eye Exams and Adult Physicals. The rationale for choosing this measure is that, in addition to bringing low-income families into the Kaiser Medical Care Program, the NHC's were to educate them to appropriately use preventive health 
care services. Thus, the second objective is to determine how well the NHC's influence a sample from the Project population to obtain particular preventive medical care services.

Finally, a secondary analysis attempts to determine characteristics associated with an "ideal" Coordinator. Identification of such characteristics would hopefully lend itself to a method of predicting which NHC's will be more successful in enhancing the health care behavior of the families they serve. Therefore, the third objective is to identify certain relevant attitudes, socio-demographic characteristics and specific dimensions of the Project's objectives which are related to the administrative staff's concept of an "ideal" Coordinator.

There are several sub-objectives of the CNHS Project that might be chosen for an evaluative study of this kind. However, many of these sub-objectives were quite specific, difficult to measure and limited in their applicability to similar projects.

Therefore, the general objectives of the CNHS Project, which have some underlying theoretical bases, seem to be the most logical foci for this study. 


\section{CHAPTER IV}

\section{EVALUATIVE RESEARCH}

The recent "War on Poverty" has intensified the need and demand for a concerted effort to evaluate the effectiveness of social action programs. These programs are presently spending billions of dollars without the benefit of increased, systematic understanding of the effectiveness of their efforts. If we are to contribute to future innovative social action programs, evaluative research must play a greater role in such programs. While evaluative research in social action settings is difficult and demanding, it is essential for the continuous assessment of present and future health and welfare programs.

The social scientist has put forth theories, some philosophical in nature, upon which action programs are currently being based. In addition to some understanding of the conceptual and theoretical aspects of the program, the methodological issues involving measurement of the effects and validity of these programs must be resolved. 


\section{DEFINITION OF EVALUATIVE RESEARCH}

Evaluation may be viewed as both an object and a process. As an object, it refers to some judgment of social worth or value. If viewed as a process, it implies the degree to which an object pos sesses a valued characteristic. The definition of social value, and the measurement of its attainment, "constitute the basic conceptual and methodological components of evaluative research. "1 Further, evaluation is also described as a process which satisfies scientific criteria and enables the investigator to describe and make adjustments toward achieving goals more effectively. ${ }^{2}$ It also "refers to the entire scope of research and analysis needed to properly carry out this program planning function; more specifically, it means measuring the extent of success toward achieving program objectives. " ${ }^{3}$ These objectives may serve as both a means to an end (sub-objective) or an end in themselves (objective).

Evaluative research, thus, aims at providing practical guidance

${ }^{1}$ Edward A. Suchman, "Principles and Practice of Evaluative Research," An Introduction to Social Research, ed. John Doby (New York: Appleton-Century-Crofts, 1967), p. 329.

2 Otto Klineberg, "The Problem of Evaluation," International Social Science Bulletin, VII, No. 3. (1955), p. 346.

${ }^{3}$ Cecil G. Sheps, and Donald L. Madison, Evaluation of Neighborhood Health Centers--A Plan for Implementation, Report to the Office of Economic Opportunity, Washington, D. C., July, 1967 (New York: Mount Sinai Medical School, 1967), p. 1. 
for the practitioner attempting to assess some program with reference to a particular objective or social worth. Evaluation of these programs may deal with the degree to which goals are achieved; and also the assessment of alternatives, and the implication of their consequences, in achieving these alternative goals.

According to Suchman, "Evaluative research is a specific form

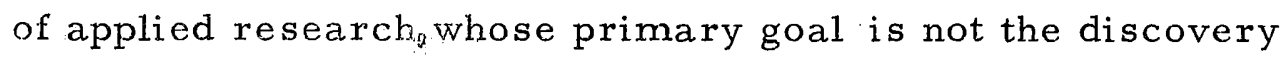
of knowledge but rather a testing of the application of knowledge. 14 In this sense, the objective of evaluative research can then be distinguished from nonevaluative research in that the major emphasis of evaluative research is upon utility and fact-finding about a specific, planned program activity. Nonevaluative research, on the other hand, is searching for new knowledge regardless of the utility of the knowledge for practical action. The primary interest here is upon studying the interrelationships of variables rather than upon the effect of controlled intervention.

\section{MODELS FOR EVALUATIVE RESEARCH}

For the most part, two general models for evaluation are of fered--the goal model and the systems model. Many variations of these models have been suggested, as well as numerous variations

${ }^{4}$ Edward A. Suchman, Evaluative Research (New York: Russell Sage Foundation, 1967), p. 75. 
in their application.

The goal model suggested by Sherwood and Freeman identifies three kinds of variables--program variables, inte rmediate va riables and dependent variables--which determine the degree to which a program succeeds. This model begins with an incoming group, possessing certain population characteristics, to whom something is done (program variables), which will in turn produce some desired change (dependent variables). The assumption is that certain attitudinal and cognitive changes which have been predicted will occur (intermediate variables). ${ }^{5}$ Sherwood and Freeman contend that measurement of the se variables should be based upon a set of theoretical concepts which trace the dynamics of how one would expect the program to obtain the desired effects. 6

Suchman's concept of "causality" also treats phenomena as a chain of interrelated events having an arbitrary beginning and ending, joined together by a number of intervening steps. ${ }^{7}$ Evaluative research, as a form of applied research must, the refore, contain the following:

${ }^{5}$ Clarence C. She rwood and Howard E. Freeman, "Research in Large Scale Intervention Programs, " The Journal of Social Issues, XXI, No. 1 (January, 1965), p. 15.

6 Ibid.

7 Suchman, "Principles and Practice of Evaluative Re search," op. cit., p. 328 . 
A hypothesis linking some independent, causal variable (social action) with a dependent, effect variable (valued consequence); and,

A method of procedure for measuring variations in the de pendent variable, and for determining the extent to which these variations are due to changes in the independent variable. 8

The goal model, then emphasizes linking input variables with output results; thereby, evaluating effectiveness. The value of "output" of the action may be influenced by the nature of the "input" as well as controlled (explained) and uncontrolled (unexplained) intervening variables. Therefore, the most crucial criteria must be applied to the identification and control of strategic variables in the goal model. In contrast to the goal model, the systems model requires the analyst to determine "how" the system solves certain problems. One of the crucial problems pertains to the functional requirements of the organizational components that must be satisfied for the system to exist and maintain itself. The focus of the inquiry then becomes the identification of the relationships of the systems components; and, to determine the degree to which these requirements are met.

A more general definition of the system model has been augmented by Etzioni who identifies two major sub-types of this model. One, he refers to as a survival model; that is, a set of operations 
which, if fulfilled, allow the system to exist. In this model, each identifiable relationship is a prerequisite for the functioning of the system. If any (of the elements and their relationships) are removed, the system ceases to operate. A second sub-type is that of the effectiveness model. Here, a pattern of inter-relations within the system is studied to determine which elements make the system most effective in attaining its goals. 9

The systems model is similar in many respects to what Weiss calls the "holistic" model. He suggests that the investigator is concerned with identifying the nature of the system, rather than focusing on particular independent-dependent variable relationships. 10

While distinctly different, both the goal and systems models offer a conceptual framework for evaluating programs. They also provide opportunity for empirical testing and subsequent theory building. In the selection of either model, three factors must be given careful consideration.

One criteria for choosing one model over the other, is "the problem" to be investigated. If the focus of evaluation is a specific

9 Amitai Etzioni, Modern Organizations (Englewood Cliffs, N. J. : Prentice-Hall, Inc., 1964), p. 19.

10 Robert Weiss, "Alternative Approaches in the Study of Complex Situations, " Human Organization, XXV, No. 3 (Fall, 1966), p. 199. 
and measurable objective of a program, the: problem is amenable to solution by using the goal model. However, if the problem is to determine the inter-relationship of various components within a program, a systems model may be employed by a social diagnostician who has background and training in organizational analysis. The approach is determined by the degree of specificity and elaboration desired in the evaluation.

$\checkmark$ Secondly, the nature and availability of data should also be taken into careful consideration prior to the selection of the research model. An extremely large, complex organization with multiplex, elusive, or conflicting goals may not lend itself to goal examination. "Unless the goal is stated explicitly, there is no basis for saying whether or not, and to what extent, it has been reached--in other words, no sound basis for evaluation. "11 However, if the goals of an organization are relatively clear, and reliable data is available for analysis, the goal model would be appropriate. The systems model "explicitly recognizes that the organization solves certain problems other than those directly involved in the achievement of goals. 12 If this more total identification is desired, the systems model should

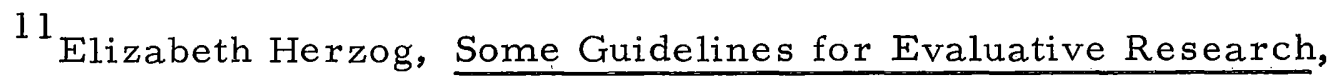
U.S. Dept. of Health, Education and Welfare, Children's Bureau Publication No. 375 (Washington: U.S. Government Printing Office, 1959), p. 12 .

${ }^{12}$ Etzioni, op. cit. , p. 17. 
be applied.

$\checkmark$ A third important criteria for consideration is the personal expertise of the investigator. The goal model requires a high degree of competence in analytical measurement and analysis on the part of the investigator. The systems model, on the other hand, demands a clinical ability to identify complex factors and relationships within a total system. The individual investigator must be knowledgeable and trained in the specific methodology each model demands. Otherwise, his contribution will fail to meet the requirements of "scientific" evaluative research.

After careful consideration of these criteria, it was decided that the goal model would be most suitable for this research project. It was determined that measurable objectives were inherent in the program and that the available data lent itself to this type of inquiry. In addition, the goal model was most appropriate to the expertise of the investigators. 


\section{CHAPTER V}

\section{METHODOLOGY}

\section{CLASSICAL EXPERIMENTAL DESIGN}

Evaluative research is first and foremost scientific research and thus, utilizes the logical basis of the scientific method. The scientific method presupposes the logic of science and the general principles of experimentation which are universally applied in all scientific disciplines. The experimental model then becomes the ideal toward which the sciences strive. Doby elucidates this point:

The experimental model more nearly approximates the ideal application of the logic of science than does any other method in scientific use. . . it can be said that experimental method is the concrete embodiment of the logical structure of science. 1

The classical experimental design of proof is the comparison of comparable groups, one of which is exposed to an experimental stimulus, while the other is not. Measurement of the groups is made both before and after the introduction of the experimental stimulus to one group. Using Samuel Stouffer's schematic diagram, it may be shown as follows:

${ }^{1}$ John Doby, "Principles of Experimentation," An Introduction to Social Research, ed. John Doby (New York: Appleton-CenturyCrofts, 1967), p. 114 。 


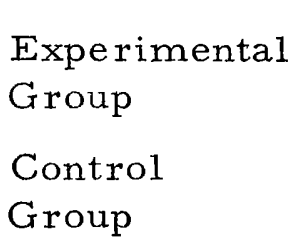

\begin{tabular}{|c|c|}
\hline BEFORE & AFTER \\
\hline$X$ & $X_{1}$ \\
$X^{\prime}$ & $X_{1}-X=d$ \\
\hline
\end{tabular}

If $d$ is significantly greater than $d^{\prime}\left(d-d^{\prime}=D\right)$, we can assume that the difference (D) is attributable to the experimental stimulus. 2 Ideally, both the experimental and control groups should be identical on all relevant characteristics. It is necessary, therefore, to select two groups that are as much alike as possible. This requirement may be satisfied by utilizing three widely used techniques: matched precision control, matched frequency distribution or randomization. Ideally, an experimental design may be carried out if, prior to the beginning of the investigation:

1. The families and individuals in a target population can be identified, and a sample randomly selected.

2. Two groups can be randomly assigned--one experimental group and one control group.

3. The experimental group receives additional services, the stimulus or independent variable, which is withheld from the control group.

2 Samuel Stouffer, "Some Observations on Study Design," Handbook of Research Design and Social Measurement, ed. Delbert Miller (New York: David McKay Co., Inc., 1964), p. 21. 
4. The dependent variables can be measured for the two groups after a specified period of time.

If these conditions are met, the research experiment will have met the requirements of the "classical" experimental design.

An alternative to randomization is matching families on "relevant" variables, assigning one to the experimental group and one to the control group. Or, the two contrasting groups may be selected and the frequency distribution of pertinent variables closely matched.

Unfortunately, in social research we rarely have these possibilities. Commenting on the social programs of the Welfare State, Chapin acknowledges that:

The conventional method of equalizing factors that are both known and also unknown (by R. A. Fisher's design experiment) is to select at random both the experimental group that receives treatment, and the control group that serves as a reference group for comparison. In social research the program of social treatment cannot be directed toward a randomly selected group because the prevailing mores require that this treatment be directed to a group of individuals who are eligible because of greater need. 3

The program philosophy at Kaiser precluded the emphasis of research and heavily stressed service, therefore, making it impossible to utilize the "classical" experimental design. For this study design, two contrasting groups were selected from the caseload of each Co: ordinator.

${ }^{3}$ F. Stuart Chapin, "Experimental Design's in Social Research," (Letter to the Editor), The American Journal of Sociology, LV, No. 4 (January, 1950), p. 402 . 


\section{RESEARCH DESIGN}

Monthly reports prepared by the Coordinators of each of the fifteen active caseloads during the last quarter of the first program year, July, August, and September, 1968, were used for the initial selection of the sample population. Contrasting samples were drawn from each caseload, assigning the ten families who had been most contacted by their NHC to the "experimental" group and the ten randomly selected families having no personal contact to the "control" group.

These names were then checked against the Daily Contact Forms to determine what type of contact had been made. (Appendix A - -Sample Monthly and Daily Contact Form) Those families who had received no personal face-to-face contacts and not more than two telephone contacts were randomly selected for the "control" group. A check with staff validated that the families in this group were still enrolled in the program, and that they had not moved or been reassigned to another NHC. (Any family about which there was some question was eliminated from the final selection.) The final contrasting samples consisted of 150 families in each group--"experimental" (most personal contact) and "control" (no personal contact).

The impact of the NHC's personal contact is evaluated on the basis of two major indices: total utilization and utilization of specific preventive health care services. To achieve this objective, 
utilization of health services at the Kaiser Foundation clinics for both contrasting samples for the first nine months of the program (October, 1967 through June, 1968), made possible by the Health Services Research Center, determined the baseline sample. Adjustments for utilization were made, taking into account that portion of both samples who had received preventive health care during the first nine months and the final utilization measure at the end of the last three months of the program's first year. Using Stouffer's model, the study can be diagramed as follows:

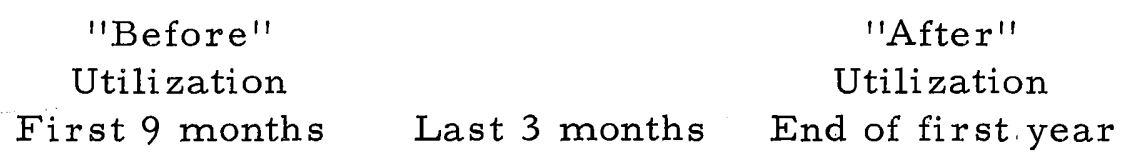

\begin{tabular}{|c|c|c|c|}
\hline $\begin{array}{l}\text { "Experimental" } \\
\text { Group }\end{array}$ & $X$ & $\begin{array}{l}\text { NHC-Most personal } \\
\text { contact with family }\end{array}$ & $x_{1}$ \\
\hline $\begin{array}{l}\text { "Control" } \\
\text { Group }\end{array}$ & $\mathrm{X}^{\prime}$ & $\begin{array}{l}\text { NHC-No personal } \\
\text { contact with family }\end{array}$ & $X_{1}^{\prime}$ \\
\hline
\end{tabular}

Except for total utilization, family members who had been seen for preventive health care services during the first nine months were not included if they returned for the same type preventive care during the last three months. That is, only those persons who had not received eye examinations during the first nine months were included in the total count of eye examinations for the last three months, etc. Others, those returning for the same type preventive care they had received during the first nine months, were only 
included in the count for total utilization during the last three months. The assumption was that during the last three month period, the concentration of effort should be directed toward that portion of people enrolled in the program who had not yet received preventive health care. Preventive health care was defined in terms of the California Relative Value Studies (CRVS) by programadminis trators, with emphasis on the specific areas of: Adult Physicals, Pap Smear Examinations, Well-Child Care, and Eye Examinations. (Appendix B)

\section{SECONDARY ANALYSIS}

Secondary to the utilization study, an analysis was made to determine attributes that may be related to the administrative staff's perception of an "ideal" Coordinator. The administrative staff was asked to rank each of the 24 Coordinators within the CNHS Project on the basis of their perception of what an "ideal" Coordinator should be. Although there were a total of 24 Coordinators, at the time of this study only fifteen had active caseloads.

One of the most important questions that is related to how well an NHC fulfills her role is in terms of the various dimensions of the Project's goals and objectives. Therefore, the administrative staff was also asked to rate the $\mathrm{NHC}^{\prime}$ s on these various dimensions.

\section{(Appendix C)}


In order to measure some specific aspects of the CNHS Project, three short questionnaires, attempting to measure knowledge of the Kaiser Health Plan and Programs, general health and community resources were developed by members of this research group. Multiple-choice questionnaires were developed from materials presented during the training program. (Appendix D)

\section{DEVELOPMENT OF QUESTIONNAIRES}

Items for the Kaiser Health Plan and Programs questionnaire were drawn from the following sources: A publication entitled "Kaiser Foundation Medical Care Program 1967"; the proposal "CNHS Project," which outlines the OEO Kaiser Health Program; and interviews with the Assistant Hospital Director, the OEO Project's Program Administrator, and a representative of the Director of the Health Plan.

Questions for the area of General Health were derived from lectures given by a Kaiser internist, pediatrician, and obstetrician during the training program. These questions were specific to the material covered and hence, quite different from the standardized health inventories.

The Community Resources questionnaire was developed by consulting two sources: the Directory of Community Resources 4

${ }^{4}$ Tri-County Community Council, Directory of Community Resources (2d ed.; Portland: Tri-County Community Council, 1965). 
and a pamphlet, "Where to Turn. $"{ }^{5}$

Both references are readily available to the Coordinators. In addition, one session of the training program was spent with a representative of the Tri-County Community Council who presented a lecture on community resources and their effective use.

For each of these three areas of knowledge--Kaiser Health Plan and Programs, General Health, and Community Resources--40 items were selected. These items were then pre-tested for clarity and understanding with a small sample of people who come from similar socio-economic backgrounds as the NHC's. The sample included:

1. For Kaiser Health Plan and Programs questionnaire, the items were presented to a group of LPN's employed by Bess Kaiser Hospital. These women approximated the educational level of the Coordinators, and were acquainted with the Kaiser Health Plan and Programs.

2. For the General Health questionnaire, a mother's' coffee group (from a low income neighborhood) that met at the Buckman Service Center participated in answering items related to health and medicine. This group is comparable in education and cultural background to those of the Coordinators.

3. For the questionnaire on Community Resources, three

${ }^{5}$ Tri-County Community Council, "Where to Turn; A Directory of Health, Welfare and Recreation Agencies." Revised. (Portland: Tri-County Community Council, 1968). 
groups of Neighborhood Service Center Aides (Brooklyn, Buckman and Sunnyside) cooperated in answering items in this area. The Aides are similar to the Coordinators in terms of the eligibility requirements for employment, as designated by the OEO.

The items were carefully scrutinized by means of paired item analysis to test their reliability. Through this analysis of the paired items, the total number of items for each questionnaire were appreciably reduced to less than 20 items per questionnaire.

To validate items in the three areas--Kaiser Health Plan and Programs, General Health, and Community Resources--experts in these areas of special interest were selected to take the questionnaire related to their area of competence. They were:

1. For Kaiser Health Plan and Programs, the Assistant Hos pital Director, the OEO Project's Program Administrator, representative of the Health Plan, and the Director of Nursing.

2. For General Health, five registered nurses at the University of Oregon Medical School.

3. For Community Resources, three social workers who had worked in the Portland area for three or more years. Two of the social workers hold MSW Degrees.

Validity was assumed if questions in the respective areas of competence were answered correctly. Any questions these experts found difficult were further eliminated. 


\section{SCALES}

Standardized health behavior inventories which measure general health knowledge and understanding of health education, at both the high school and college level were also administered to the NHC's. ${ }^{6}$ Since one of the primary concerns of the Kaiser CNHS Project is improving the health care behavior of the indigent, one would expect that Coordinators who were ranked high by administrative staff would score higher on health knowledge than those ranked low.

In addition to the health behavior inventories, several attitudinal scales were associated with administrative staff's perception of an "ideal" Coordinator. These attitudinal scales covered the following areas:

1. Achievement orientation, as presented by Kahl, was used because, ". . it is an index of the generalized motivation to do well, to excel at a variety of tasks. $" 7$ Only the "occupational primacy" dimension of this scale was utilized. Occupational primacy measures ". . achievement values that put occupational success

${ }^{6}$ E. Harold LeMaistre and Marion B. Pollock, "Health Behavior Inventory: Senior High Level," (Monterey: California Test Bureau, 1962).

Carmen Patricia Reid, "Health Behavior Inventory: College Level," (Monterey: California Test Bureau, 1966).

${ }^{7}$ Joseph Kahl, "Some Measurements of Achievement Orientation," The American Journal of Sociology, LXX (May, 1965), p. 678 . 
ahead of alternative possibilities. "8 It was assumed that an "ideal" Coordinator would demonstrate a higher degree of motivation than those of lower ranking.

2. Another scale employed was Srole's eunomia-anomia continuum representing, " . . the individual's generalized, pervasive sense of 'self belongingness' at one extreme compared with 'self-toothers distance' and 'self-to-others alienation' at the other pole of the continuum. "9 A high degree of "self-to-others distance" or "self-to-others alienation" would not be indicative of an ability to adequately serve as a "gatekeeper," or linkage, between the medical care system and the specific population served.

3. Neal and Seeman's short form of the Powerlessness Scale was used to measure another dimension of alienation. ${ }^{10}$ Powerlessness is associated with the individual's perception of internal versus external control of both positive and negative events. Internal control refers to perception of events occurring as a result of one's own behavior, therefore under the individual's personal control. On

${ }^{8}$ Ibid., p. 671 .

${ }^{9}$ Leo Srole, "Social Integration and Certain Corollaries: An Exploratory Study," American Sociological Review, XXI (1956), p. 711 .

10 Arthur G. Neal and Melvin Seeman, "Organizations and Powerlessness: A Test of the Mediation Hypothesis," American Sociological Review, XXIX (April, 1964), p. 219. 
the other hand, external control refers to the perception of events as something that is beyond the control of the individual. ${ }^{11}$ The Coordinator in her role is encouraged to influence behavioral change in others; and hence, she must feel that it is within one's power to influence environmental events affecting one's life.

4. A short form dogmatism scale (10 item) was used to measure the extent to which an individual is intolerant toward those with beliefs that are in opposition to his own. Because this measure correlates reliably with the original 40 item scale, the ten item scale was used. ${ }^{12}$ The NHC's are expected to be tolerant of the beliefs and practices of others, even though they may differ from their own.

Other available measures included some socio-demographic characteristics, age and education, of the Coordinators. Although originally obtained for other purposes, they were utilized in the present study as they relate to rank.

${ }^{11}$ Charles M. Bonjean, Richard J. Hill, and S. Dale McLencore, Sociological Measurement: An Inventory of Scales and Indices (San Francisco: Chandler Publishing Co., 1967), p. 28.

12 Rolf H. K. Schulze, "A Shortened Version of the Rokeach Dogmatism Scale, " Journal of Psychological Studies, LXV (July, $1962)$, p. 94.

Troldah1, Verling C. and Frederick A. Powell, "A Short Form Dogmatism Scale for Use in Field Studies, "Social Forces, XLIV (December, 1965). 


\section{STATISTICS}

The primary objective of this study is to determine whether there is a relationship between NHC's contacts and the families' utilization of the medical care services. Since the study design differentiates the independent variable by selecting contrasting samples, "most personal contact" group and "no personal contact" group, a statistic was used to help interpret the differences of the proportions of utilization between these two contrasting samples. One statistic appropriate for this study involves the significance of difference between the sample proportions. This statistic computes the per cent of standard deviation using the normal curve model and specifies

the degree of probability of the difference of proportions occurring. ${ }^{13}$ Since some of the sample totals are large and the proportions of differences small, the utilization of this statistic is justified for the heuristic interpretation of the data.

\section{SUMMARY}

Evaluative research, as all other research, attempts to meet

${ }^{13}$ The statistic used to compute the level of significance in Tables I through VI is "the percent of standard deviation outside of the normal curve from which one can obtain the probability of a difference this large or larger occurring. " James B. Williams, Statistical Analysis: Olivetti Underwood Programma 101, (Marketing Services Division, Olivetti Underwood Corp. , August, 1968), pp. 194-196. See also Hubert M. Blalock, Jr. Social Statistics (New York: McGraw-Hill Book Co., Inc., 1960), pp. 149-152. 
the requirements of the ideal "classical" experimental design. When circumstances prohibit the achievement of this ideal, research strives to approximate this ideal as closely as possible.

For the present research design, contrasting samples were drawn from each of the fifteen active caseloads within the Kaiser CNHS Project. Those families or individuals who had received the most personal contacts with their NHC (ten from each caseload) were assigned to the "experimental" group; and those families or individuals who had received no personal contact from their NHC were randomly selected (ten from each caseload) and assigned to the "control" group. Two major indices, utilization of total out-patient medical care services and utilization of four specific areas of preventive health care services by the "experimental" and "control" groups, are the basis upon which the impact of the NHC's is measured.

Secondary to the utilization study, an attempt is made to identify characteristics that may be related to administrative staff's perception of an "ideal" Coordinator. The administrative staff was first asked to numerically rank each of the 24 Coordinators in terms of their perception of an "ideal" Coordinator. They were then asked to rate each Coordinator on several dimensions that approximated the objectives of the NHC training program, using a five point scale. Several attitudinal scales, tests of knowledge, and the 
socio-demographic characteristics of age and education were then related to rank in order to determine factors that might reflect and possibly predict, the administrative staff's perception of an "ideal" Coordinator. 
CHAPTER VI

ANALYSIS OF THE DATA

\section{EFEECTIVENESS OF NHC'S AS "GATEKEEPERS":} THE PRIMARY ANALYSIS

\section{Total Utilization of Out-patient Services}

The first objective of this study is to determine the effects of the NHC'S on the total utilization of out-patient health services by contrasting samples from the CNHS Project. From available data indicating the number of out-patient clinic services received by families, monthly rates of utilization per 100 persons were computed. Table I shows that for the "most personal contact" group this rate increased from an average of 37.8 for the first nine months to 54. 2 for the last three months of the first Project year. This increase is significant at the .04 level. On the other hand, the "no personal contact" group showed a decrease in their monthly rate of utilization per 100 persons from 29.3 to 19.2 clinic visits, but this difference is not significant. It appears that not only do personal, face-to-face contacts with the indigenous non-professional favorably influence the health care behavior, but also the lack of contact or only minimal telephone contact with an NHC may result in a negative 
TABLE I

COMPARISONS BETWEEN TIME PERIODS ON MONTHLY RATE OF UTILIZATION OF OUT-PATIENT SERVICES PER 100 PERSONS BY TWO GROUPS DIFFERING IN CONTACT

\begin{tabular}{|c|c|c|c|c|}
\hline Group & $\begin{array}{l}\text { Rates of } \\
\text { Oct., }{ }^{167-} \\
\text { June, }{ }^{168}\end{array}$ & 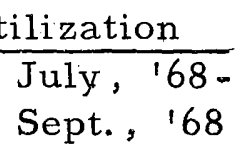 & $\begin{array}{c}\text { Differences } \\
\text { between } \\
\text { Rates }\end{array}$ & $\begin{array}{c}\text { Level } \\
\text { of } \\
\text { Significance }\end{array}$ \\
\hline $\begin{array}{l}\text { "Most personal } \\
\text { contact" }\end{array}$ & $\begin{array}{c}37.8 \\
(N=729)\end{array}$ & $\begin{array}{c}54.2 \\
(N=733)\end{array}$ & 16.4 & $\mathrm{P}<.04$ \\
\hline $\begin{array}{l}\text { "No personal } \\
\text { contact" }\end{array}$ & $\begin{array}{c}29.3 \\
(N=667)\end{array}$ & $\begin{array}{c}19.2 \\
(N=667)\end{array}$ & -10.1 & NS \\
\hline \multicolumn{5}{|c|}{$\begin{array}{l}\mathrm{N}=\text { The number of persons in each group. Discrepancies between } \\
\text { time periods are due to births and marriages. } \\
\mathrm{P}=\text { The probability of a difference this large or larger occurring in } \\
\text { the same population, as computed from raw data. } \\
\text { NS = Not significant at the } .05 \text { level, as computed from raw data. }\end{array}$} \\
\hline
\end{tabular}

effect on health care behavior. Unfortunately information regarding the amount of contact families had with Coordinators prior to July, 1968, was not available. Daily and monthly contact report forms were not instituted until June, 1968, so it was not possible to determine the effects of changes in the rate of personal contact during the first

${ }^{1}$ The statistic used to compute the level of significance in Tables I through VI is "the percent of standard deviation outside of the normal curve from which one can obtain the probability of a difference this large or larger occurring. " James B. Williams, Statistical Analysis: Olivetti Underwood Programma 101, (Marketing Services Division, Olivetti Underwood Corp., August, 1968), pp. 194-196. See also Hubert M. Blalock, Jr. Social Statistics (New York: McGrawHill Book Co., Inc., 1960), pp. 149-152. 
project year.

\section{Utilization of Preventive Services}

The second objective of this study is to determine how well the NHC's influence families they serve to obtain particular preventive medical care services, i.e. Well Child Care, Adult Physicals, Pap Smear Examinations, and Eye Examination.

Table II reports the proportion of persons in the "most personal contact" group who had received each of the preventive health care services by the end of the ninth month and the twelfth month periods of the first project year. This table shows the increase during the last three months in the proportion of persons in the "most personal contact" group, who made use of each of these services, was quite significant. The proportion of children receiving Well Child Care services increased from 23 per cent to 30 per cent which is significant at the .03 level. The proportion of adults who received physical examinations increased from 36 per cent to 46 per cent which is significant at the .04 level. The increase from 43 per cent to 58 per cent in the number of women who received Pap Smear Examinations is the most significant at the .01 level. Finally, an increase from 12 per cent to 16 per cent for Eye Examinations is also significant at the .03 level. The differences between time periods found for these groups seem to indicate that the NHC's have 
TAB LE II

COMPARISONS BETWEEN TIME PERIODS ON PROPORTION OF UTILIZATION BY PREVENTIVE HEALTH CARE SER VICE FOR THE "MOST PERSONAL CONTACT" GROUP

\begin{tabular}{|c|c|c|c|c|}
\hline Service & $\begin{array}{l}\text { Proportion } \\
\text { Oct., } 167- \\
\text { June, }{ }^{1} 68\end{array}$ & $\begin{array}{l}\frac{f \text { Utilization }}{\text { Oct., }}{ }^{167-} \\
\text { Sept., } 168\end{array}$ & $\begin{array}{c}\text { Increase } \\
\text { in the } \\
\text { Proportion }\end{array}$ & $\begin{array}{c}\text { Level } \\
\text { of } \\
\text { Significance }\end{array}$ \\
\hline Well Child & $\begin{array}{c}23 \% \\
(N=507)\end{array}$ & $\begin{array}{c}30 \% \\
(N=510)\end{array}$ & $7 \%$ & $\mathrm{P}<.03$ \\
\hline Adult Physical & $\begin{array}{c}36 \% \\
(N=222)\end{array}$ & $\begin{array}{c}46 \% \\
(N=223)\end{array}$ & $10 \%$ & $\mathrm{P}<.04$ \\
\hline Pap Smear & $\begin{array}{c}43 \% \\
(N=143)\end{array}$ & $\begin{array}{c}58 \% \\
(N=144)\end{array}$ & $15 \%$ & $\mathrm{P}_{1}<.01$ \\
\hline Eye Exam & $\begin{array}{c}12 \% \\
(N=729)\end{array}$ & $\begin{array}{c}16 \% \\
(N=733)\end{array}$ & $4 \%$ & $\mathrm{P}<.03$ \\
\hline \multicolumn{5}{|c|}{$\begin{array}{l}\mathbf{N}=\text { The total number of persons. Discrepancies between time } \\
\text { periods are due to births and marriages. } \\
P=\text { The probability of a difference this large or larger occurring in } \\
\text { the same population, as computed from raw data. }\end{array}$} \\
\hline
\end{tabular}

a favorable influence on the health behavior of their clients. Similar comparisons are presented for the "no personal contact" group in Table III.

In the "no personal contact" group there were slight increases from the end of the ninth to the end of the twelfth month of the first project year in the proportion of persons using the selected preventive health care services. Although a few people in this group 
TABLE III

COMPARISONS BETWEEN TIME PERIODS ON PROPORTION OF UTILIZATION BY PREVENTIVE HEALTH CARE SERVICE FOR THE "NO PERSONAL CONTACT" GROUP

\begin{tabular}{|c|c|c|c|c|}
\hline Service & $\begin{array}{l}\text { Proportion } \\
\text { Oct., ' } 67- \\
\text { June, ' } 68\end{array}$ & $\begin{array}{l}\text { f Utilization } \\
\text { Oct., '67- } \\
\text { Sept., } 168\end{array}$ & $\begin{array}{l}\text { Increase } \\
\text { in the } \\
\text { Proportion }\end{array}$ & $\begin{array}{c}\text { Level } \\
\text { of } \\
\text { Significance }\end{array}$ \\
\hline Well Child & $\begin{array}{c}27 \% \\
(\mathrm{~N}=445)\end{array}$ & $\begin{array}{c}29 \% \\
(\mathrm{~N}=445)\end{array}$ & $2 \%$ & NS \\
\hline Adult Physical & $\begin{array}{c}26 \% \\
(\mathrm{~N}=222)\end{array}$ & $\begin{array}{c}31 \% \\
(\mathrm{~N}=222)\end{array}$ & $5 \%$ & NS \\
\hline Pap Smear & $\begin{array}{c}32 \% \\
(\mathrm{~N}=145)\end{array}$ & $\begin{array}{c}37 \% \\
(\mathrm{~N}=145)\end{array}$ & $5 \%$ & NS \\
\hline Eye Exam & $\begin{array}{c}11 \% \\
(\mathrm{~N}=667)\end{array}$ & $\begin{array}{c}13 \% \\
(\mathrm{~N}=667)\end{array}$ & $2 \%$ & NS \\
\hline
\end{tabular}

did obtain these various services during the three month period in question, the increases are not significant as they are for the "most personal contact" group. This evidence supports the contention that indigenous non-professionals favorably influence the health practices of their clients.

Interpretation of the Utilization Data

Although it can be inferred from the data that the amount of contact with a Coordinator is related to the utilization of health 
services by the families they serve, there are several questions that can be raised in regard to these findings. The "most personal contact" groups which were used in this analysis make up only about an eighth of each caseload. This sample cannot be considered representative of the entire caseload, in that these families received a great deal more of the Coordinator's attention than did the average family in the CNHS Project.

Computations using the contacts reported by Coordinators for the last three months produce some interesting results. There was an average of eighteen, and no less than seven, families in each caseload of approximately 80 families for whom no personal or telephone contacts were reported by the Coordinators on either daily or monthly forms. These figures are based only on those families Coordinators reported as part of their caseloads, and who were officially enrolled in the program throughout this period. Coordinators' monthly report forms indicated that an average of 143 face-toface contacts with clients were made by each Coordinator during this three month period. This is the equivalent of 2.23 contacts per working day. Daily report forms listed fewer contacts. An average of 59 of the contacts shown on the monthly report forms were made with the ten "most personal contact" families. This means that approximately 40 per cent of the contacts reported by Coordinators for this period were with one-eighth of the CNHS Project population. 
In view of these facts one should be very cautious in making any interpretations regarding the relative effectiveness of such a program as opposed to one without the provision of Coordinator services. If the average utilization of health services by families in Coordinators' caseloads had been compared with the average for a group of families enrolled in a similar project without Coordinators, different results may have been obtained.

The wide variation in the number of contacts with families in each caseload may be interpreted in a number of ways. Caseloads may be so large as to necessitate the concentration of the Coordinators' efforts on a few families at the expense of others. Certain families in each caseload may be much more convenient for the Coordinator to contact due to these families' proximity to the Coordinator's own place of residence or to the area of concentration of her caseload. For Coordinators who do not have an automobile (onethird do not), this factor of proximity would be of special importance. Finally, if no adult member of a family is home during the Coordinator's working hours, it would be less likely that they would be contacted and it would also be less likely for these families to make appropriate use of medical services.

Comparisons between rates of utilization of out-patient services for the two groups are presented in Table IV. The data show that the "most personal contact" group's utilization during the first 
TABLE IV

COMPARISONS BETWEEN GROUPS (DIFFERING IN CONTACT)

ON MONTHLY RATE OF UTILIZATION OF OUT-PATIENT SERVICES PER 100 PERSONS BY TIME PERIOD

\begin{tabular}{|c|c|c|c|c|}
\hline & \multicolumn{2}{|c|}{ Rate of Utilization } & \multirow[b]{2}{*}{$\begin{array}{l}\text { Difference } \\
\text { between } \\
\text { Rates }\end{array}$} & \multirow[b]{2}{*}{$\begin{array}{c}\text { Level } \\
\text { of } \\
\text { Significance }\end{array}$} \\
\hline $\begin{array}{c}\text { Time } \\
\text { Periods }\end{array}$ & $\begin{array}{c}\text { "Most Personal } \\
\text { Contact" } \\
\text { Group* }\end{array}$ & $\begin{array}{c}\text { "No Personal } \\
\text { Contact" } \\
\text { Group* }\end{array}$ & & \\
\hline $\begin{array}{ll}\text { Oct. , } & 167- \\
\text { June, } & 168\end{array}$ & $\begin{array}{c}37.8 \% \\
(N=729)\end{array}$ & $\begin{array}{c}29.3 \% \\
(N=667)\end{array}$ & 8.5 & $\mathrm{P}<.02$ \\
\hline $\begin{array}{l}\text { July, } 168- \\
\text { Sept. , }\end{array}$ & $\begin{array}{c}54.2 \% \\
(N=733)\end{array}$ & $\begin{array}{c}19.2 \% \\
(\mathrm{~N}=667)\end{array}$ & 35.0 & $\mathrm{P}<.01$ \\
\hline \multicolumn{5}{|c|}{$\begin{aligned} *= & \text { These two groups were selected from information recorded on } \\
& \text { the monthly forms which were available only for the period of } \\
& \text { July, } 1968-\text { Sept. } 1968 . \\
\mathrm{N}= & \text { The number of persons in each group. Discrepancies between } \\
& \text { time periods are due to births and marriages. } \\
\mathrm{P}= & \text { The probability of a difference this large or larger occurring } \\
& \text { in the same population, as computed from raw data. }\end{aligned}$} \\
\hline
\end{tabular}

nine months of the first project year was already greater than that for the "no personal contact" group. Figures for the last three months show an even greater difference between the groups. This increased difference in utilization is apparently the result of the Coordinators' working more intensively with the "most personal contact" group. These results support the contention that the health care seeking behavior of those enrolled in the CNHS Project is positively influenced by the frequency of contact with NHC's. It appears 
that the concentration of contacts with the first group and the lack of personal contact with the second group increasingly differentiated the utilization patterns between these two contrasting groups.

Another possible explanation for the discrepancies in amount of contact with NHC's and in utilization of health services may be that families with "no personal contact" have minimal health problems and have consistently made appropriate use of preventive health services. They would, therefore, have less need for medical services and consequently have less need to be contacted by a Coordinator. In order to determine whether this was, in fact, the case, further analyses were made to compare the differences between the "most personal contact" and the "no personal contact" groups for the first nine months. Table V presents differences in the utilization of the various preventive services by these two groups during this period. Each of the services except Well Child Care were used by a larger percentage of persons in the "most personal contact" group than in the "no personal contact" group. The data show that utilization of specific preventive services, except for Adult Physicals, did not differ significantly between the two contrasting groups during the first nine months. Thus it can be concluded that prior patterns of utilization of preventive health services were not a deciding factor in determining what families in the sample were contacted during the last three months of the first project year. 
TABLE V

COMPARISONS BETWEEN GROUPS (DIFFERING IN CONTACT) ON PROPORTION OF UTILIZATION BY PREVENTIVE HEALTH CARE SERVICE FOR THE FIRST NINE MONTHS OF THE FIRST PROJECT YEAR

\begin{tabular}{|c|c|c|c|c|}
\hline Service & $\begin{array}{c}\text { Proportion } \\
\text { "Most Perso } \\
\text { Contact" } \\
\text { Group* }\end{array}$ & $\begin{array}{c}\text { Jtilization } \\
\text { No Person } \\
\text { Contact" } \\
\text { Group* }\end{array}$ & Difference & $\begin{array}{c}\text { Level } \\
\text { of } \\
\text { Significance }\end{array}$ \\
\hline Well Child & $\begin{array}{c}23 \% \\
(N=507)\end{array}$ & $\begin{array}{c}27 \% \\
(\mathrm{~N}=445)\end{array}$ & $4 \%$ & NS \\
\hline Adult Physical & $\begin{array}{c}36 \% \\
(N=222)\end{array}$ & $\begin{array}{c}26 \% \\
(\mathrm{~N}=222)\end{array}$ & $10 \%$ & $\mathrm{P}<.02$ \\
\hline Pap Smear & $\begin{array}{c}43 \% \\
(\mathrm{~N}=143)\end{array}$ & $\begin{array}{c}32 \% \\
(N=145)\end{array}$ & $11 \%$ & NS \\
\hline Eye Exam & $\begin{array}{c}12 \% \\
(\mathrm{~N}=729)\end{array}$ & $\begin{array}{c}11 \% \\
(\mathrm{~N}=667)\end{array}$ & $1 \%$ & NS \\
\hline \multicolumn{5}{|c|}{$\begin{aligned} * & \text { These two groups were selected from information recorded on } \\
& \text { the monthly forms which were available only for the period } \\
& \text { July, } 1968-\text { Sept. } 1968 . \\
\mathrm{N}= & \text { The total number of persons. } \\
\mathrm{NS}= & \text { Not significant at the } 05 \text { level, as computed from raw data. } \\
\mathrm{P}= & \text { The probability of a difference this large or larger occurring } \\
& \text { in the same population, as computed from raw data. }\end{aligned}$} \\
\hline
\end{tabular}

Table VI shows the comparisons between groups on the proportion of utilization of out-patient services for the last three months. It is clear that a significantly greater proportion of persons in the "most personal contact" group utilized each of these services than did persons in the "no personal contact" group. The utilization 
TABLE VI

COMPARISONS BETWEEN GROUPS (DIFFERING IN CONTACT)

ON PROPORTION OF UTILIZATION BY PREVENTIVE

HEALTH CARE SERVICE FOR THE LAST THREE

MONTHS OF THE FIRST PROJECT YEAR

\begin{tabular}{|c|c|c|c|c|}
\hline Service & $\begin{array}{c}\text { Proportior } \\
\text { "Most Perso } \\
\text { Contact" } \\
\text { Group }\end{array}$ & $\begin{array}{l}\text { Utilization } \\
\text { 'No Persor } \\
\text { Contact" } \\
\text { Group }\end{array}$ & Difference & $\begin{array}{c}\text { Level } \\
\text { of } \\
\text { Significance }\end{array}$ \\
\hline Well Child & $\begin{array}{c}8 \% \\
(N=392)\end{array}$ & $\begin{array}{c}3 \% \\
(\mathrm{~N}=327)\end{array}$ & $5 \%$ & $\mathrm{P}<.01$ \\
\hline Adult Physical & $\begin{array}{c}15 \% \\
(\mathrm{~N}=143)\end{array}$ & $\begin{array}{c}7 \% \\
(\mathrm{~N}=165)\end{array}$ & $8 \%$ & $\mathrm{P}<.02$ \\
\hline Pap Smear & $\begin{array}{c}28 \% \\
(N=83)\end{array}$ & $\begin{array}{c}8 \% \\
(\mathrm{~N}=99)\end{array}$ & $20 \%$ & $\mathrm{P}<.01$ \\
\hline Eye Exam & $\begin{array}{c}4 \% \\
(\mathrm{~N}=648)\end{array}$ & $\begin{array}{c}2 \% \\
(\mathrm{~N}=593)\end{array}$ & $2 \%$ & $\mathrm{P}<.04$ \\
\hline $\begin{aligned} \mathbb{N}= & \text { The total } \\
P= & \text { The proba } \\
& \text { the same }\end{aligned}$ & $\begin{array}{l}\text { umber of pe } \\
\text { oility of a di. } \\
\text { opulation, a }\end{array}$ & this 1 & $\begin{array}{l}\text { or large } \\
\text { w data. }\end{array}$ & curring in \\
\hline
\end{tabular}

of Well Child Care services by the "most personal contact" group was 8 per cent during the last three months, while it was only 3 per cent for the "no personal contact" group. This pattern is the reverse of that which was shown for the first nine months and is significant at the . 01 level. These data strongly suggest that the Coordinators are highly effective in influencing their clients to obtain preventive medical services for their children. This is based on the assumption 
that these changes are primarily due to similar changes in the number of contacts made by Coordinators with these families.

A similar effect was seen in the case of Adult Physicals. The "most personal contact" group had 15 per cent utilization of the se services, while only 7 per cent of the "no personal contact" group utilized these services during the same time period. This difference is significant at the .02 level.

Differences were also found between the two groups for Pap Smear Examinations. The proportion of utilization for this service during the last three months was 28 per cent for the "most personal contact" group while only 8 per cent for the "no personal contact" group. This difference was significant at the .01 level.

The proportion of utilization of the Eye Examination services was 4 per cent for the "most personal contact" group and only 2 per cent for the "no personal contact" group. This difference in the proportion of utilization of Eye Examinations is significant at the .04 level for the last three months. This increase in the significance of the difference between the two groups was the result of a decrease in utilization of this service by the "no personal contact" group rather than an increase in the utilization by the "most personal contact" group.

An inherent shortcoming for this study is that the research component was not an integral part of the administration of the CNHS 
Project. This situation may have prevented the authors from making an accurate determination of the eligibility of the families and whether or not these families considered themselves eligible for medical care services throughout the first project year. There were indications that some Coordinators may have informed certain families that they were no longer eligible for the project without officially deleting them.

One of the most important methodological shortcomings is the fact that previous factors influencing the health behavior of individual family members were impossible to control because of the very nature of the program and its operation. The lack of control over the assignment of families to the two contrasting samples precludes this study from making any definitive statements about the relationships found.

Additional errors may have been introduced due to the status of the data from which these results were obtained. The Coordinators' system for reporting contacts with clients was a recent innovation, and NHC's may not have had time to perfect it. The discrepancy between the number of contacts reported on the daily forms, and the number of contacts reported on monthly forms may be due to the Coordinators' failure to consistently submit daily contact forms on each personal interview.

In spite of the shortcomings of this study, the data clearly show 
that contact with Coordinators is positively related to utilization of medical care services. Therefore future studies concerned with the effectiveness of such programs must take into account the amount of contact the low-income families have with indigenous non-professionals as well as the nature of these contacts.

\section{CHARACTERISTICS OF AN "IDEAL" NEIGHBORHOOD HEALTH COORDINATOR: THE SECONDARY ANALYSIS}

The third objective of this study is to identify certain relevant attitudes, socio-demographic characteristics and specific dimensions of the Project's objectives which might be related to the administrative staff's perception of the "ideal" Coordinator. A better measure of the Coordinator's performance would have been the frequency and quality of contacts she makes with her clients and their utilization of health services, but this information was not readily available. In order to obtain such data, a much more extensive study would have been required.

Coordinators were numerically ranked by the three members of the administrative staff on the basis of their perception of the "ideal" Coordinator. There was a high correlation among staff members in the ranking of the NHC's, as demonstrated by the Spearman rank correlation coefficients $\left(\mathrm{r}_{\mathrm{s}}\right)$ of $.52, .70$, and .59 for the 
paired rankings. ${ }^{2}$ Since this correlation is significant at the .01

level, an average rank was computed for each of the 24 Coordinators.

The average rank of the Coordinators was then used as the dependent variable in the secondary analysis.

In addition to ranking the NHC's, each member of the administrative staff was asked to list the personal characteristics he considered most important in a good NHC. The most salient characteristics mentioned may be categorized as follows:

1. Interpersonal Relationships

a. Capacity to relate to people.

b. Interest and ability in working with people.

2. Personality Type or Personal Dispositions
a. Warmth
b. Sensitivity
c. Flexibility

3. Knowledge and Learning Ability
a. Ability to learn new information
b. Aptitude in learning better ways to perform one's work
c. Ability to understand problems and work out the best solutions
d. Ability to act as situations and needs dictate
e. Ability to perceive clients' needs

2 Sidney Siegel, Nonparametric Statistics for the Behavioral Sciences (New York: McGraw-Hill Book Co., Inc., 1956), pp. 202212. The observed Spearman Rank Correlation Coefficient, $r$, was tested to determine its significance. The observed Rho coefficients differed from zero (no association) significantly that these coefficients could not have occurred by chance. 
4. Individual Growth and Maturation

a. Maturity in recognizing and coping with one's own problems

b. Willingness to receive advice and help

These categories of characteristics closely resemble some dimensions of the objectives of the Kaiser CNHS Project, which were the basis of questions used for rating the NHC's.

Coordinators were rated by the administrative staff on a five point scale--Superior, Above Average, Average, Below Average, and Needs Definite Improvement--on each of the following questions:

1. Knowledge dimension--Does she demonstrate knowledge and understanding of the objectives and procedures of comprehensive medical care?

2. Skill in human relations--To what degree has she shown ability and skill in working with people and in basic human relations?

3. Initiative--Has she shown initiative in assuming individual responsibility for her job as a Neighborhood Health Coordinator?

4. Utilization of Resources--How adept is she in using community resources?

5. Self-awareness--To what degree has she benefited from the orientation training in self-awareness?

6. Ability to work with colleagues--How well does she work or interact with the other Neighborhood Health Coordinators?

7. Over-all Evaluation--What is your personal over-all evaluation of her as a Neighborhood Health Coordinator ${ }^{3}$

These questions are pertinent to some specific aspects of the CNHS

${ }^{3}$ See Appendix C. 
Project's Training Program, and as can be seen, are highly associated with characteristics considered important by members of the administrative staff. Since the same staff members both ranked and subsequently rated each Coordinator on the basis of these questions, one would expect a high association between these dimensions. See Appendix $\mathrm{E}$ for tables showing the relationship between rating scores and rank.

The tables in Appendix $\mathrm{E}$ show that the rating scores for each of the seven questions are, in fact, associated with rank. Personal over-all evaluation of the Coordinators (Table XXV) and ability to relate and cooperate with colleagues (Table XXIV) show the highest degree of association with rank. Because Coordinators were ranked by the administrative staff's perception of the "ideal" Coordinator, the close association of personal over-all evaluation to rank would be expected.

The high association between one's ability to work with her colleagues (Table XXIV) and rank indicates the importance of this attribute in the administrative staff's ranking of the Coordinators. It may also be due to a greater degree of familiarity, by the staff, with this aspect of the Coordinators' functioning. It can be further speculated that positive relationships with fellow workers tend to enhance Coordinators in their own performance, or that the staff considered the ability to work with one's associates as indicative of 
an ability to get along with people in general, which includes working with clients.

The difference in the relationship with rank between this item and the preceding one (Personal over-all evaluation of Coordinators) may be due to the fact that it is a more specific dimension of interpersonal relations, and hence, more difficult to evaluate. A more accurate interpretation, perhaps, is that question two has two dimensions within its context,--ability and skill--the reby complicating precise evaluation.

Self-awareness (Table XXIII) had the third closest relationship to rank, and is indicative of an assumption frequently made in social work, i.e. self-awareness is a prerequisite for understanding others.

One objective of the CNHS Project is to upgrade the Coordinators' skills in order to qualify them for the regular labor market. Therefore, the administrative staff also rated Coordinators on their employability outside the CNHS Project by indicating job areas in which each might qualify. (Appendix C)

Members of the administrative staff concurred that seven of the 24 Coordinators would be able to obtain employment outside the CNHS Project, and that five of the Coordinators would not. There was a division of opinion on the employability of the twelve remaining Coordinators. Table VII shows the number of Coordinators who 
TABLE VII

\section{NUMBER DISTRIBUTIONS OF COORDINATORS CONSIDERED BY ONE OR MORE OF THE PROJECT STAFF TO BE \\ EMPLOYABLE IN THE REGULAR LABOR \\ MARKET BY AREA OF EMPLOYABILITY}

\begin{tabular}{|lc|}
\hline \multicolumn{1}{r|}{$\begin{array}{c}\text { Area of } \\
\text { Employability }\end{array}$} & $\begin{array}{c}\text { Coordinators Qualified } \\
\text { For Each Area }\end{array}$ \\
\cline { 2 - 2 } & Number \\
Social Service & 15 \\
Clerical & 6 \\
Education & 4 \\
Administration & 4 \\
Nursing & 3 \\
Laboratory Technician & 2 \\
Librarian & 1 \\
Hostess & 1 \\
Sales & 1 \\
& \\
There were 24 NHC's who were rated by three staff administrators. \\
The number reflects one or more staff choices per NHC. \\
\hline
\end{tabular}

were considered by at least one of the three staff members qualified for employment in certain specific areas. The large number of Coordinators who were considered qualified for employment in other positions of social service seems to reflect the staff's feeling that these Coordinators have developed some skill in this particular area. It is not known if the Coordinators had skills in the se particular areas before joining the Project, or if the staff's estimations are, in fact, realistic. Permanent employment outside the CNHS Project would be a more valid measure. 
The relationship between some specific attitudinal scales and tests of knowledge and rank were also examined in an attempt to identify characteristics associated with the "ideal" Coordinator. Three of the tests of knowledge---two standardized health behavior inventories (high school and college level) and one specific to ma:terial covered during the training program--were related to general health knowledge and understanding of health education.

Table VIII shows that scores for the high school level health behavior inventory are not related to rank. On the other hand, the relationship between scores on the college level health behavior inventory and rank indicate a small negative relationship (Table IX). These findings are not what might be expected in a program designed to improve the health practices of the poor.

TABLE VIII

PERCENTAGE DISTRIBUTIONS OF SCORES ON THE CALIFORNIA HEALTH BEHAVIOR INVENTORY - -HIGH SCHOOL LEVEL BY RANK OF NEIGHBORHOOD HEALTH COORDINATORS

\begin{tabular}{|c|c|c|c|}
\hline \multirow[b]{2}{*}{ Rank } & & \multicolumn{2}{|c|}{ Score } \\
\hline & & $\overline{\mathrm{High}}$ & Low \\
\hline High & & $50 \%$ & $50 \%$ \\
\hline \multirow[t]{3}{*}{ Low } & & $50 \%$ & $50 \%$ \\
\hline & Total & $\overline{100} \%$ & $\overline{100 \%}$ \\
\hline & Number & 12 & 12 \\
\hline
\end{tabular}


TABLE IX

PERCENTAGE DISTRIBUTIONS OF SCORES ON THE CALIFORNIA HEALTH BEHAVIOR INVENTORY - COLLEGE LEVEL BY RANK OF NEIGHBORHOOD HEALTH COORDINATORS

\begin{tabular}{|lccc|}
\hline \multirow{2}{*}{ Rank } & \multicolumn{2}{c|}{ Score } & Low \\
\hline High & & High & $57 \%$ \\
& Total & $43 \%$ & $\frac{43 \%}{100 \%}$ \\
& Number & $\frac{57 \%}{100 \%}$ & 12 \\
\hline
\end{tabular}

The percentage distribution of scores for the test of general health knowledge specific to material covered in the training program, as they relate to rank, are shown in Table $\mathrm{X}$. The figures

TABLE X

PERCENTAGE DISTRIBUTIONS OF SCORES ON THE GENERAL HEALTH QUESTIONNAIRE BY RANK OF NEIGHBORHOOD HEALTH COORDINATORS

\begin{tabular}{|lccc|}
\hline \multirow{2}{*}{ Rank } & \multicolumn{3}{c|}{ Score } \\
\hline High & High & Low \\
\hline Low & Total & $54 \%$ & $45 \%$ \\
& Number & $\frac{46 \%}{100 \%}$ & $\frac{55 \%}{100 \%}$ \\
& & 13 & 11 \\
\hline
\end{tabular}


again indicate that knowledge in the area of general health is slightly related to rank. It appears that general health knowledge and understanding of health education were not as salient as other variables in ranking of Coordinators.

Two other specific measures of knowledge which covered the areas of the Kaiser Health Plan and Programs and community resources were related to rank. Although both areas were emphasized during the training program, and appear to be rather important aspects of the Coordinator's role, the data show a slight negative relationship with rank (Tables XI and XII). These measures, therefore, reflect characteristics which are not related or negatively associated with an "ideal" Coordinator.

TABLE XI

PERCENTAGE DISTRIBUTIONS OF SCORES ON THE KAISER HEALTH PLAN AND PROGRAMS QUESTIONNAIRE BY RANK OF NEIGHBORHOOD HEALTH COORDINATORS

\begin{tabular}{|lccc|}
\hline \multirow{2}{*}{ Rank } & \multicolumn{3}{c|}{ Score } \\
\cline { 3 - 4 } High & High & Low \\
\hline & Total & $44 \%$ & $53 \%$ \\
& Number & $\frac{56 \%}{100 \%}$ & $\frac{47 \%}{100 \%}$ \\
& & 9 & 15 \\
\hline
\end{tabular}


TABLE XII

PERCENTAGE DISTRIBUTIONS OF SCORES ON THE COMMUNITY

RESOURCES QUESTIONNAIRE BY RANK OF

NEIGHBORHOOD HEALTH COORDINATORS

\begin{tabular}{|lccc|}
\hline \multirow{2}{*}{ Rank } & & \multicolumn{2}{c|}{ Score } \\
\cline { 3 - 4 } High & & High & Low \\
\hline Low & & $44 \%$ & $53 \%$ \\
& Total & $\frac{56 \%}{100 \%}$ & $\frac{47 \%}{100 \%}$ \\
& Number & 9 & 15 \\
\hline
\end{tabular}

Attitudinal scales that were associated with rank include:

the occupational primacy scale (a dimension of achievement orientation), the anomia scale, powerlessness scale, and a short-form dogmatism scale. The relationship between the occupational primacy scale and rank is shown in Table XIII. This scale is designed to measure values that place occupational success ahead of alternative life goals. The direction of this relationship with rank, although slightly positive, suggests that persons who feel a need for occupational success tend to more closely approximate administrative staff's perception of an "ideal"' Coordinator than those who do not.

Kahl suggests that the "striver," as measured by this scale, is characteristically a person in the lower middle-class "who has achieved some occupational success as a skilled worker or foreman, 
TABLE XIII

\section{PERCENTAGE DISTRIBUTIONS OF SCORES ON THE OCCUPATIONAL PRIMACY SCALE BY RANK OF NEIGHBORHOOD HEALTH COORDINATORS}

\begin{tabular}{|c|c|c|c|}
\hline \multirow[b]{2}{*}{ Rank } & & \multicolumn{2}{|c|}{ Score } \\
\hline & & $\mathrm{High}$ & Low \\
\hline $\mathrm{High}$ & & $57 \%$ & $43 \%$ \\
\hline \multirow[t]{3}{*}{ Low } & & $43 \%$ & $57 \%$ \\
\hline & Total & $100 \%$ & $100 \%$ \\
\hline & Number & 12 & 12 \\
\hline
\end{tabular}

but did not have much educational preparation. "4 ${ }^{4}$ The NHC's are similar in background, and are in a position in which the role requires acquisition of institutionally oriented values. It appears that the NHC's who were ranked in the top half of the group are those who might have acquired the norms of the Kaiser Medical Care System. Being employed by a health institution, they may also have identified with, and become a part of, the system. In this sense they have "arrived"; therefore, they are similar to the foreman or the skilled worker who has established himself in an industrial setting.

Scores on the other three scales (anomia, powerlessness, and dogmatism) show inverse relationships to rank. However, the

\footnotetext{
${ }^{4}$ Joseph A. Kah1, op. cit., p. 677.
} 
negative direction of these relationships would be expected due to the nature of these scales and of the characteristics they are measuring. Table XIV shows the percentage distributions of scores on the anomia scale in relation to rank. The findings indicate that this characteristic is independent of rank. On the other hand, scores on the

\section{TABLE XIV}

PERCENTAGE DISTRIBUTIONS OF SCORES ON THE ANOMIA SCALE BY RANK OF NEIGHBORHOOD HEALTH COORDINATORS

\begin{tabular}{|lccc|}
\hline \multirow{2}{*}{ Rank } & \multicolumn{2}{c|}{ Score } \\
\hline High & & $50 \%$ & Low \\
Low & Total & $\frac{50 \%}{100 \%}$ & $55 \%$ \\
& Number & 12 & $\frac{45 \%}{100 \%}$ \\
& & & 11 \\
\hline
\end{tabular}

powerlessness and dogmatism scales show a higher degree of relationship to rank.

In Table XV the percentage distributions of scores on the powerlessness scale by rank indicate that a person who feels she has a high degree of control over environmental events more closely approximates an "ideal" Coordinator. Conversely, a person who feels less confident in her mastery of external events ranks lower 
TABLE XV

\section{PERCENTAGE DISTRIBUTIONS OF SCORES ON THE POWERLESSNESS SCALE BY RANK OF NEIGHBORHOOD HEALTH COORDINATORS}

\begin{tabular}{|lccc|}
\hline \multirow{2}{*}{ Rank } & \multicolumn{2}{c|}{ Score } \\
\hline High & High & Low \\
\hline Low & Total & $37 \%$ & $62 \%$ \\
& Number & $\frac{63 \%}{100 \%}$ & $\frac{38 \%}{100 \%}$ \\
& 11 & 13 \\
\hline
\end{tabular}

in relation to the "ideal" Coordinator.

Similar interpretations can be made from Table XVI, which shows a corresponding relationship between scores on the shortform dogmatism scale and rank. This inverse relationship with rank indicates that Coordinators who tend to be less dogmatic, i.e. more tolerant of beliefs that are different from their own, were ranked high.

In Tables XIV, XV, and XVI, the relationships of anomia, powerlessness, and dogmatism with rank clearly show the general direction of the relationship between these variables. Although the magnitude of the associations is not definitive, it is expressive of the positive attitude and orientation of the NHC's. 
TABLE XVI

PERCENTAGE DISTRIBUTIONS OF SCORES ON A SHORTENED VERSION OF THE ROKEACH DOGMATISM SCALE BY RANK OF NEIGHBORHOOD HEALTH COORDINATORS

\begin{tabular}{|c|c|c|c|}
\hline \multirow[b]{2}{*}{ Rank } & & \multicolumn{2}{|c|}{ Scale } \\
\hline & & High & Low \\
\hline High & & $38 \%$ & $64 \%$ \\
\hline \multirow[t]{3}{*}{ Low } & & $62 \%$ & $36 \%$ \\
\hline & Total & $\overline{100 \%}$ & $\overline{100 \%}$ \\
\hline & Number & 13 & 11 \\
\hline
\end{tabular}

In addition, the socio-demographic variables of age and education were related to rank. Table XVII shows the inverse relationship found between age and rank. This reflects the tendency of staff to

TABLE XVII

PERCENTAGE DISTRIBUTIONS OF AGES BY RANK OF NEIGHBORHOOD HEALTH COORDINATORS

\begin{tabular}{|lccc|}
\hline \multirow{2}{*}{ Rank } & & \multicolumn{2}{c|}{ Age } \\
\hline High & & High & Low \\
\hline Low & Total & $43 \%$ & $57 \%$ \\
& Number & $\frac{57 \%}{100 \%}$ & $\frac{43 \%}{100 \%}$ \\
& & 12 & 12 \\
\hline
\end{tabular}


rank younger Coordinators (below the age of 39) more favorably.

A similar relationship is found between level of education and rank, as seen in Table XVIII. The direction of this relationship

TABLE XVIII

PERCENTAGE DISTRIBUTIONS OF LEVEL OF EDUCATION BY RANK OF NEIGHBORHOOD HEALTH COORDINATORS

\begin{tabular}{|c|c|c|c|}
\hline \multirow[b]{2}{*}{ Rank } & & \multicolumn{2}{|c|}{ Educational Level } \\
\hline & & High & Low \\
\hline High & & $38 \%$ & $56 \%$ \\
\hline \multirow[t]{3}{*}{ Low } & & $62 \%$ & $44 \%$ \\
\hline & Total & $\overline{100 \%}$ & $\overline{100 \%}$ \\
\hline & Number & 8 & 16 \\
\hline
\end{tabular}

indicates that Coordinators who have attained an educational level equivalent to less than one year of formal education beyond high school more closely approximate an "ideal" Coordinator. In other words, high educational attainment is not necessarily an important criteria for performance in the role of an NHC as suggested by rank. It is recognized that there are other variables not included in the secondary analysis which may have been considered by the administrative staff in their evaluation of the Coordinators. Some of the characteristics mentioned in their criteria of an "ideal" Coordinator were not included in this analysis because they were 
difficult to measure.

Caution should be used in interpreting the relationships found in the secondary analysis, since the total size of the sample was extremely small. Because of these circumstances, the investigators refrained from making any definitive statements about the magnitude of the relationships found. Rather, this analysis placed special emphasis on the directions of the relationships as indicated. 


\section{CHAPTER VII}

\section{SUMMARY AND CONCLUSIONS}

\section{SUMMARY}

Since the establishment of the poverty programs throughout the country, little in the way of evaluative research with regard to the impact of programs launched under the auspices of the OEO has been completed. While this study does not purport to be an exhaustive analysis of the Kaiser CNHS Project, it does examine a specific aspect of the Project. The primary purpose of this study was to evaluate the role of the NHC's within the CNHS Project. The underlying theoretical framework for the CNHS Project was articulated by an existing theory that indigenous non-professional persons, serving in a formalized role, act as "gatekeepers" linking the lowincome population with the medical care system. Some of the findings do point the way for future evaluative research in OEO Projects which are utilizing indigenous non-professionals as "gatekeepers" between the poverty population and the existing institutions within the community.

The primary goals of this particular CNHS Project include 
providing pre-paid medical care for low-income families within the framework of the existing Kaiser Medical Care Program, and educating these low-income families to fully and appropriately utilize medical care services. Although this study does not measure the extent to which these goals are being met, findings show that the NHC's personal contacts with these families make a positive contribution toward this end. In analyzing the difference in utilization patterns between those families having the most NHC contacts and those with no NHC contacts, it is questioned whether or not all families enrolled in this program are receiving optimum CNHS Project services which are available to them.

\section{CONCLUSIONS}

Three objectives, posed in Chapter III, served as guidelines for this study. The first was to determine the effect of the frequency of NHC's contact on the utilization of total medical care services by a sample of families enrolled in the CNHS Project. Analysis of the utilization data supports the philosophy upon which these Coordinators were hired and trained; that is, NHC's are effective in promoting an increase in the over-all utilization of medical care services by families with whom they have the "most personal contact." Conversely, having "no personal contact" is related to lower utilization of out-patient medical services by the families enrolled 
in the program.

The second objective was to determine whether the NHC's were effective in encouraging families to obtain appropriate preventive health services. The findings indicate that families, seen by the Coordinators most frequently, did make greater use of preventive health care services than did those families having no contact, or only limited telephone contact, with the NHC's.

The third objective was to determine the characteristics which might be associated with the administrative staff's perception of an "idea1" Coordinator. For this purpose several CNHS Project ob $\overline{\bar{y}}$ jectives, attitudinąl scales, tests of knowledge, and socio-demographic characteristics, as they relate to the rank of the Coordinator, were used. The relationships between the ratings on several CNHS Project objectives and the ranking of the Coordinators by the administrative staff indicated that the dimension of "getting along with colleagues" had the highest association with rank, suggesting that behavior which is most observable to the administrative staff may have influenced how the Coordinators were ranked. The findings substantiated the expected relationship between positive attitudes toward life, and rank of an NHC. On the other hand, age and education were found to be negatively associated with rank. This suggests that younger women who have the equivalent of and not more than one year post-high school education, more nearly approximate the 
"ideal" NHC.

\section{RECOMMENDATIONS}

The findings of this study, suggest some alternative approaches that may facilitate some realization of the Project's objectives. It is on this basis that the following recommendations are being made:

1. The NHC's should be routinely notified of families who are not utilizing appropriate medical care services, so they will make special effort to contact these families.

2. In order to improve the over-all rate of Coordinator contacts with their families, the administrators should consider: (a) reducing the size of caseloads carried by each Coordinator; (b) reducing the size of geographic area served by each NHC (one-third must rely on public transportation to reach their families); and (c) increasing the number of supervisors available to NHC's so that attention is promptly given whenever a Coordinator has difficulty reaching a specific family:

3. Consideration should be given to redesigning the daily and monthly contact forms to improve the recording of contacts by NHC's. The present NHC record-keeping system was, at times, found to be incomplete and inconsistent. Involvement of the Coordinators in designing a new system of recording should be considered. In the 
course of this study, it was observed that several Coordinators had developed their own methods of record-keeping which might easily be adapted for project use. The training program should include some orientation toward record-keeping, the reasons for it, and instruction in accurate reporting.

4. In order to define and clarify the role of the NHC, a job description manual should be published. This would provide guidelines for the NHC's, administrative staff, and other persons inter ested in the CNHS Project.

In addition to the above recommendations, it is suggested that an on-going evaluative research component be incorporated into all programs such as the CNHS Project. Implementation of such an internal research process would provide invaluable feedback to determine how well such innovative OEO Programs are fulfilling their objectives. Research of this kind should not be considered a threat to the existence of such programs, but rather a challenge and a means for developing more effective ways to utilize indigenous non-professionals. In addition, the administrative staffs of such programs should always be looking at new ways and ideas for implementing or realigning present programs. 


\section{A SELECTED BIBLIOGRAPHY}

Ackoff, Russell L. The Design of Social Research. Chicago: The University of Chicago Press, 1953.

Adorno, Theodor, et al. The Authoritarian Personality. New York: Harper and Bros., 1950.

American Home Economics Association. Working With Low-Income Families. Proceedings of the AHEA Workshop, University of Chicago, Center for Continuing Education, March 15-19, 1965. Washington: American Home Economics Association, 1965.

Arensberg, Conrad, and Arthur Niehoff. Introducing Social Change. Chicago: Aldine Publishing Co., 1964.

Biddle, Bruce J., and Edwin J. Thomas. Role Theory: Concepts and Research. New York: John Wiley and Sons, Inc., 1966.

Blalok, Hubert M., Jr. Social Statistics. New York: McGrawHill Book Company, Inc., 1960.

Blau, Peter M. "Social Mobility and Interpersonal Relations," in Social Perspectives on Behavior. Edited by Herman D. Stein and Richard M. Cloward.. Glencoe: Free Press, 1958.

pp. $470-475$.

Bonjean, Charles M., Richard J. Hill, and S. Dale McLemore.

Sociological Measurement: An Inventory of Scales and Indices. San Francisco: Chandler Publishing Co., 1967.

Borgetta, Edgar F. "Role and Reference Group Theory," in Social Science Theory and Social Work Research. Edited by Leonard S. Kagan. New York: National Association of Social Workers, 1960. pp. 16-27.

Brager, George A., and Francis P. Purcell. Community Action Against Poverty. New Haven: College and University Press, 1967. 
Brooks, Michael P. "The Community Action Program as a Setting for Applied Research," Journal of Social Is sues, XXI (January, 1965), $29-40$.

Campbell, D. T. "Factors Relevant to the Validity of Experiments in Social Setting, "Psychological Bulletin, LIV (July, 1957), 297-312.

Chapin, F. Stuart. "Experimental Designs in Social Research," (Letter to the Editor), The American Journal of Sociology, LV, No. 4 (January, 1950), $401-403$.

Colombo, Theodore J., Ernest W. Saward, and Merwyn R. Greenlick. "The Integration of an O. E. O. Health Program into a Prepaid Comprehensive Group Practice Plan. "Unpublished report to the American Public Health Association, Detroit, November 13, 1968.

Cronbach, L. J. Essentials of Psychological Testing. 2d ed. New York: Harper and Bros., 1960.

Dasgupta, Sugata. Social Work and Social Change. Boston: Porter Sargent, 1968.

Dean, John P., Robert L. Eichhorn, and Lois R. Dean. "The Survey," in An Introduction to Social Research. Edited by John Doby. New York: Appleton-Century-Crofts, 1967. pp. $244-273$.

Doby, John. "Principles of Experimentation," in An Introduction to Social Research. Edited by John Doby. New York: AppletonCentury-Crofts, 1967 . pp. 113-155.

Etzioni, Amitai. Modern Organizations. Englewood Cliffs, New Jersey: Prentice-Hall, Inc., 1964.

Fairweather, George. Methods for Experimental Social Innovation. New York: John Wiley and Sons, Inc., 1967.

Festinger, Leon, and Daniel Katz. Research Methods in the Behavioral Sciences. New York: Holt, Rinehart and Winston, 1953.

Francis, Roy. "Some Application of Experimentation," in An Introduction to Social Research. Edited by John Doby. New York: Appleton-Century-Crofts, 1967. pp. 156-186. 
Getting, Vlado A., et al. "Research in Evaluation in Public Health Practices." A paper presented at the 92nd Annual Meeting of the American Public Health Association, New York, Octobe $r$ $5,1964$.

Glidewell, John C., et al. "Health Department Research in Mental Health, " Ame rican Journal of Public Health, XLVIII (March, $1958), 362-368$.

Gorden, Margaret S. Poverty in America. San Francisco: Chandler Publishing Co., 1965.

Gordon, Jesse E. "Project Cause, the Federal Anti-Poverty Program, and Some Implications of Subprofessional Training," American Psychologist, XX, No. 5 (May, 1965), 334-343.

Greunberg, Ernest M. (ed.). "Evaluating the Effectiveness of Mental Health Service," Millbank Memorial Fund Quarterly, XLIV, Pt. 2 (January, 1966), 11-15.

Grosser, Charles F. "Local Re sidents as Mediators Between Middle Class Professional Workers and Lower Class Clients," Social Service Review, XL (March, 1966), 56-63.

Hallowitz, Emanuel, and Frank Riessman. "The Role of the Indigenous Non-professional in a Community Health Neighborhood Service Center Program," American Journal of Orthopsychiatry, XXXVII, No. 4 (July, 1967), 766-778.

Handy, Rollo, and Paul Kurtz. A Current Appraisal of the Behavioral Sciences. Great Barrington, Mass,: Behavioral Research Council, 1964.

Hawley, Paul. "Evaluation of Quality Patient Care," American Journal of Public Health, XLV (December, 1955), 1533-1537.

Hayes, Samuel P., Jr. Evaluating Development Projects. (A Manual for the Use of Field Workers). UNESCO, 1966.

Heath, Alice M. "Health Aides in Health Departments," Public Health Reports, LXXXII, No. 7 (July, 1967), 608-614.

Herzog, Elizabeth. Some Guidelines for Evaluative Research. U. S, Department of Health, Education and Welfare, Children's Bureau Publication No. 375 (Washington: U. S. Government Printing Office, 1959). 
Hunter, Robert. Poverty. New York: Harper and Row, 1965.

Hyman, Herbert H., Charles R. Wright, and Terence K. Hopkins. Applications of Methods of Evaluation: Four Studies of the Encampment for Citizenship. Berkeley: University of California Press, 1962.

Irelan, Lola M. (ed.). Low-Income Life Styles. U. S. Department of Health, Education and Welfare, Welfare Administration Publication No. 14 (Washington: U. S. Government Printing Office, 1966).

Kahl, Joseph. "Some Measurements of Achievement Orientation," The American Journal of Sociology, LXX (May, 1965), 669-681.

Kaiser Foundation Medical Care Program Report, 1960. Oakland, California: Public Affairs Department, Foundation Health Plan, Inc., 1961.

Kaiser Foundation Medical Care Program Report, 1967. Oakland, California: Public Affairs Department, Foundation Health Plan, Inc., 1968.

Kaiser Foundation Research Institute (Delegate Agency). "Comprehensive Neighborhood Health Services Project, Narrative for Quarterly Report, October-December, 1967." Office of Economic Opportunity--Community Action Program Grant \#CG-ORE-67-8392. Portland, Oregon, 1968.

- "Comprehensive Neighborhood Health Service Project," Narrative for the Proposal for Office of Economic Opportunity-Community Action Program Grant \#CG-ORE-67-8392. Portland, Oregon, 1967.

- "Comprehensive Neighborhood Health Services: Progress Report and Work Plan for Program Year 2." Office of Economic Opportunity--Community Action Program Grant \#CG-ORE-67-8392. Portland, Oregon, 1968.

Kerner, Otto, et al. Report of the National Advisory Commission on Civil Disorders. New York: E. P. Dutton and Co., Inc., 1968.

Klineberg, Otto, "The Problem of Evaluation, " International Social Science Bulletin, VII, No. 3 (1955), 346-352. 
Kurtz, Norman P. "Gatekeepers in the Process of Acculturation," Unpublished Ph. D. dissertation, Department of Sociology, University of Colorado, 1966.

LaRocco, August (ed.). Poverty and Health in the United States: A Bibliography with Abstracts. New York: Medical and Health Research Association, 1967.

LeMaistre, E. Harold, and Marion B. Pollock. "Health Behavior Inventory: Senior High Level, " Monterey: California Test Bureau, 1962.

Levinson, Perry, and Jeffrey Schiller. "Role Analysis of the Indigenous Nonprofessional," Social Work, XI, No. 3 (July, 1966), $95-101$.

Lippitt, Ronald. Training in Community Relations. New York: Harper and Bros., 1949.

Loomis, Charles P. Social Systems. Princeton, New Jersey:

D. Van Nostrand Co., Inc., 1960.

.. "Systemic Linkage of E1 Cerrito,". Rural Sociology, XXIV (March, 1959), 54-57.

Lowenberg, Frank M. "Social Workers and Indigenous Nonprofessionals: Some Structural Dilemmas," Social Work, XIII, No. 3 (July, 1968), 65-71.

MacDonald, Mary E. "Social Work Research: A Perspective," in Social Work Research. Edited by Norman Polansky. Chicago: University of Chicago Press, 1960. pp. 1-23.

McFadden, G. M. et al. "How Do Nurses Spend Their Time in Schools?" American Journal of Public Health, XLVII (August, 1957), 937-943.

MacMahon, Brian, Thomas F. Pugh, and George B. Hutchinson. "Principles in the Evaluation of Community Mental Health Programs," American Journal of Public Health, LI (July, 1961), 963-979.

Marris, Peter, and Martin Rein. Dilemmas of Social Reform.

New York: Atherton Press, 1967. 
Merton, Robert K., Leonard Broom, and Leonard S. Cottrell, Jr. (eds.). Sociology Today: Problems and Prospects. New York: Basic Books, Inc., 1959.

Meyer, Henry J., Edgar F. Borgetta, and Wyatt C. Jones. Girls at Vocational High: An Experiment in Social Work Intervention. New York: Russell Sage Foundation, 1965.

Neal, Arthur G., and Melvin Seeman. "Organizations and Powerlessness: A Test of the Mediation Hypothesis, "American Sociological Review, XXIX (Apri1, 1964), $216-225$.

Office of General Counsel, Office of Economic Opportunity. Narrative Summary of the Economic Opportunity Amendments of 1966. Washington: U.S. Government Printing Office, 1967 :

Pearl, Arthur, and Frank Riessman. New Careers for the Poor. New York: Free Press, 1966.

Peter, Hollis W. (ed.). Comparative Theories of Social Change. Ann Arbor, Michigan: Foundation for Research on Human Behavior, 1966.

Phillips, Bernard. Social Research: Strategy and Tactics. New York: MacMillan Co., 1966.

Public Law 88-452. "Economic Opportunity Act." August 20, 1964, Section 2.

Public Law 89-794: "Comprehensive Health Services Programs." November 8; 1966; Section 211-12:

Reid, Carmen Patricia. "Health Behavior Inventory: College Level," Monterey: California Test Bureau, 1966.

Reiff, Robert, and Frank Riessman. The Indigenous Nonprofessional: A Strategy of Change in Community Mental Health Programs. Mental Health Program Report No. 3. New York: National Institute of Labor Education, November, 1964.

Rein, Martin, and Frank Riessman. "A Strategy for Antipoverty Community Action Program," Social Work, XI, No. 2 (April, 1966), 3-12. 
Riecken, Henry. W. The Volunteer Work Camp: A Psychological Evaluation. Cambridge, Mass.: Addison-Wesley Press, 1952.

Riessman, Frank. "The Helper Therapy Principle," Social Work, $\mathrm{X}$, No. 2 (April, 1965), 27-32.

- The Revolution in Social Work: the New Professional. A Report Prepared by the Riessman--Training Department Mobilization for Youth, and U rban Studies Center, Rutgers University, New Brunswick, New Jersey, 1963.

- Some Further Thoughts on the New Non-Professional.

New York: New York University, April, 1966. (Mimeographed.)

Roman, Melvin, and Sally Jacobson. "Progress Report: Training of Mental Health Aides." New York: Lincoln Hospital Mental Health Services, Albert Einstein College of Medicine, December, 1965. (Mimeographed.)

Sheps, Cecil G., and Donald L. Madison. Evaluation of Neighborhood Health Centers--A Plan for Implementation. Report to the Office of Economic Opportunity, Washington, D. C., July, 1967. New York: Mt. Sinai Medical School, 1967.

Schulze, Rolf H. K. "A Shortened Version of the Rokeach Dogmatism Scale, " Journal of Psychological Studies, XIII (July, 1962), 93-97.

Sherwood, Clarence C., and Howard E. Freeman. "Research in Large-Scale Intervention Programs," The Journal of Social Issues, XXI, No. 1 (January, 1965), 11-27.

Shostak, Arthur B., and William Gomberg. New Perspectives on Poverty. Englewood Cliffs, New Jersey: Prentice-Hall, Inc., 1965.

Siegel, Sidney. Nonparametric Statistics for the Behavioral Sciences. New York: McGraw-Hill Book Co., Inc., 1956.

Smalley, Ruth Elizabeth. Theory for Social Work Practice. New York: Columbia University Press, 1967. 
Srole, Leo. "Social Integration and Certain Corollaries: An Exploratory Study," American Sociological Review, XXI (December, 1956), 709-716.

Stouffer, Samuel. "Some Observations on Study Design," in Handbook of Research Design and Social Measurement. Edited by Delbert Miller. New York: David McKay Co., Inc., 1964. pp. 20-26.

Suchman, Edward A. Evaluative Research. New York: Russell Sage Foundation, 1967.

- "Principles and Practice of Evaluative Research," in An Introduction to Social Research. Edited by John Doby. New York: Appleton-Century-Crofts, 1967. pp. 328-333.

Thomas, Edwin, and Donna McLeod. "A Research Evaluation of In-Service Training and of Reduced Work Loads in Aid to Dependent Children," Public Welfare, XVI (April, 1958), 109-112 and 132-134.

Tri-County Community Council. Directory of Community Resources. 2d ed. revised. Portland: Tri-County Community Council, 1965.

- "Where to Turn: A Directory of Health, Welfare and Recreation Agencies." Revised. Portland: Tri-County Community Council, 1968.

Troldahl, Verling C., and Frederick A. Powell. "A Short-Form Dogmatism Scale for Use in Field Studies, "Social Forces, XLIV (December, 1965), 211-214.

Truax, Charles B. "Training of Nonprofessional Personnel in Therapeutic Interpersonal Relationships, " American Journal of Public Health, LVII, No. 10 (October, 1967), 1778-1791.

Webster's Seventh New Collegiate Dictionary. Springfield, Mass.: G. \& C. Merriam Co., 1963.

Weiss, Carol H. "Utilization of Evaluation: Toward Comparative Study, "Paper presented at the American Sociological Association Meeting, Miami Beach, September 1, 1966. 
Weiss, Robert. "Alternative Approaches in the Study of Complex Situations," Human Organization, XXVIII, No. 3 (Fall, 1966), 198-205.

- Statistics in Social Research: An Introduction. New York: John Wiley and Sons, Inc., 1968.

Williams, James B. Statistical Analysis: Olivetti Underwood Programma 101. Marketing Services Division, Olivetti Underwood Corp., August, 1968.

White, Elijah L. "Age and Income Differentials in Selected Aspects of Morbidity, Disability and Utilization of Health Services, " Inquiry, V, No. 1 (March, 1968), 18-30.

Zelditch, Morris, Jr. A Basic Course in Sociological Statistics. New York: Holt, Rinehart and Winston, Inc., 1966.

Zetterberg, Hans. "On the Decisions in Verification Studies," in Handbook of Research Design and Measurement. Edited by Delbert Miller. New York: David McKay Co., Inc., 1964. pp. 26-31. 


\section{APPENDIX A}

\section{SAMPLE MONTHLY AND DAILY CONTACT FORMS}

Month of

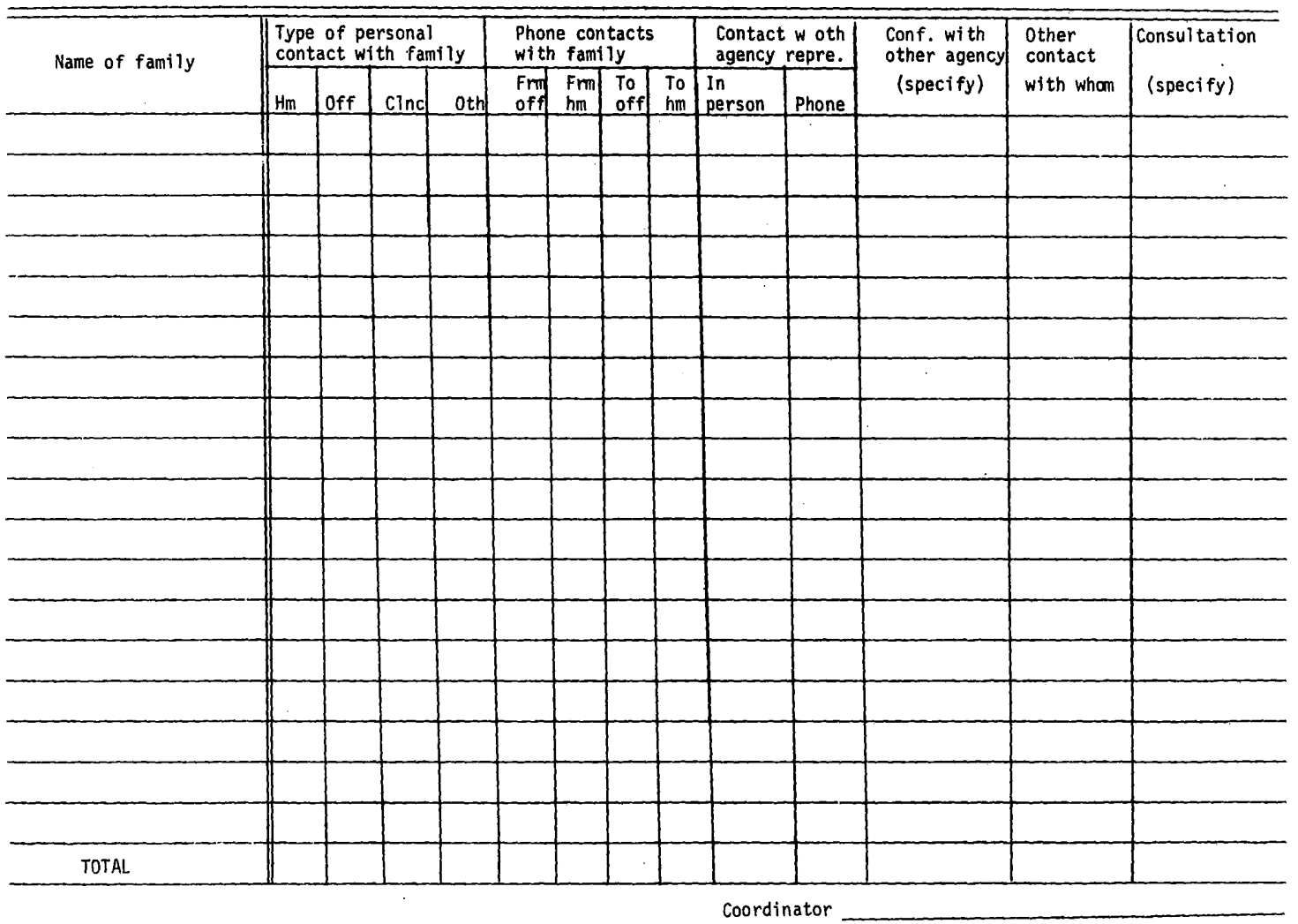


COMPREHENSIVE NEIGHBORHOOD

HEALTH SERVICES

Coordinator's Name

Group Number

Client's Name

(Last) (First) (Middle)

Chart Number Health Plan ID

1. Date of Contact:

Tmonth) (day), (year)

2. Day of Contact:

$$
S M T W \text { Th } F \text { S }
$$

3. Time of Contact: 9:00-12:00 (during service hrs.) $Ð$ Not during service hrs.

4. Place of Contact:

$\square$ Client's home
Neighborhood Service Center
clinic
Kaiser OEO Office
Other 2 (specify)

5. Subject of Contact:

$\square$ Subscriber
Dependent of above
clinic
Kaiser OEO Office
Other _ (specify)

6. Status of Contact:

$$
\square \text { Initial }
$$

7. Nature of Contact:

$\square$ Solicitation
Take application
Routine
Emergency
Transportation
Other Tspecify

8. Referral Source:

$\square$ Neighborhood Service Center

$\Xi$ other family on project

$\square$ Social Worker

$\square$ school

$\square$ Other OEO Agency

other specify)

(spectfy)

9. Health Service Rendered (by Aide)

$\square$ Urge client to make appointment

$\exists$ Provide transportation to $\mathrm{clinic}$

$\exists$ Discuss cancelled appointments

$\square$ other

10. Non-health services rendered:

Referred to:

$\square$ Neighborhood Service Center

$\square$ Salvation Army

$\square$ Red Cross

$\square$ Weifare

$\square$ Sunshine Division

$\square$ Legal Aid

$\square$ Church

other

11. Avaflability of information about family -May contact:

$\square$ Welfare

$\square$ Netghborhood Service Center $\square$ other 
12. (a) Assessment of family needs (such as medical, dental, legal, employment, food and clothing, and family counseling):

(b) Plans for future contact (routine visits to home, telephone, no immediate contact, termination):

13. Additional comments: 


\section{CALIFORNIA RELATIVE VALUE STUDIES CODES AS REVISED BY KAISER FOUNDATION}

Selected codes used in a prior evaluation by the administrative staff of the OEO Project.

WELL CHILD

9036 Well Child Care

\section{ADULT PHYSICAL}

9000 Pre-operative History and Physical Exam

9003 Complete Physical Exam

9006 Premarital Exam

9009 Complete Physical with Known Chronic Morbidity

9012 School Physical Exam and Administrative Reasons

9013 Insurance Physical Exam

4823 Prenatal Care

4824 Postpartum Visit

\section{PAP SMEAR}

8.911 Cytologic Study (Papanicolaou Type) Screening only

4513 Pap Smear (8911 is the laboratory procedure for same)

\section{EYE EXAMINATION}

5400 Refraction of Patient Not Wearing Glasses

5413 Non-refraction Visit to Optometrist

5415 Prism Cover Test

5416 Refraction of Patient Now Wearing Glasses

5417 Indirect Ophthalmoscopy

5418 Ophthalmodynomometry 


\section{APPENDIX C}

\section{SAMPLE RATING FORM}

On the scale indicated below rate each Neighborhood Coordinator by checking the appropriate column:

1. Does he demonstrate knowledge and under-.. standing of the objectives and procedures of comprehensive medical care?

2. To what degree has he shown ability and skill in working with people and basic human relations?

3. Has he shown initiative in as suming individual responsibility for his job as NHC?

4. How adept is he in using appropriate community resources?

5. To what degree has he benefited from the orientation training in self-awareness?

6. How well does he work or interact with the other $\mathrm{NHC}^{\prime} \mathrm{s}$ ?

7. What is your personal over-all evaluation of him as a NHC?

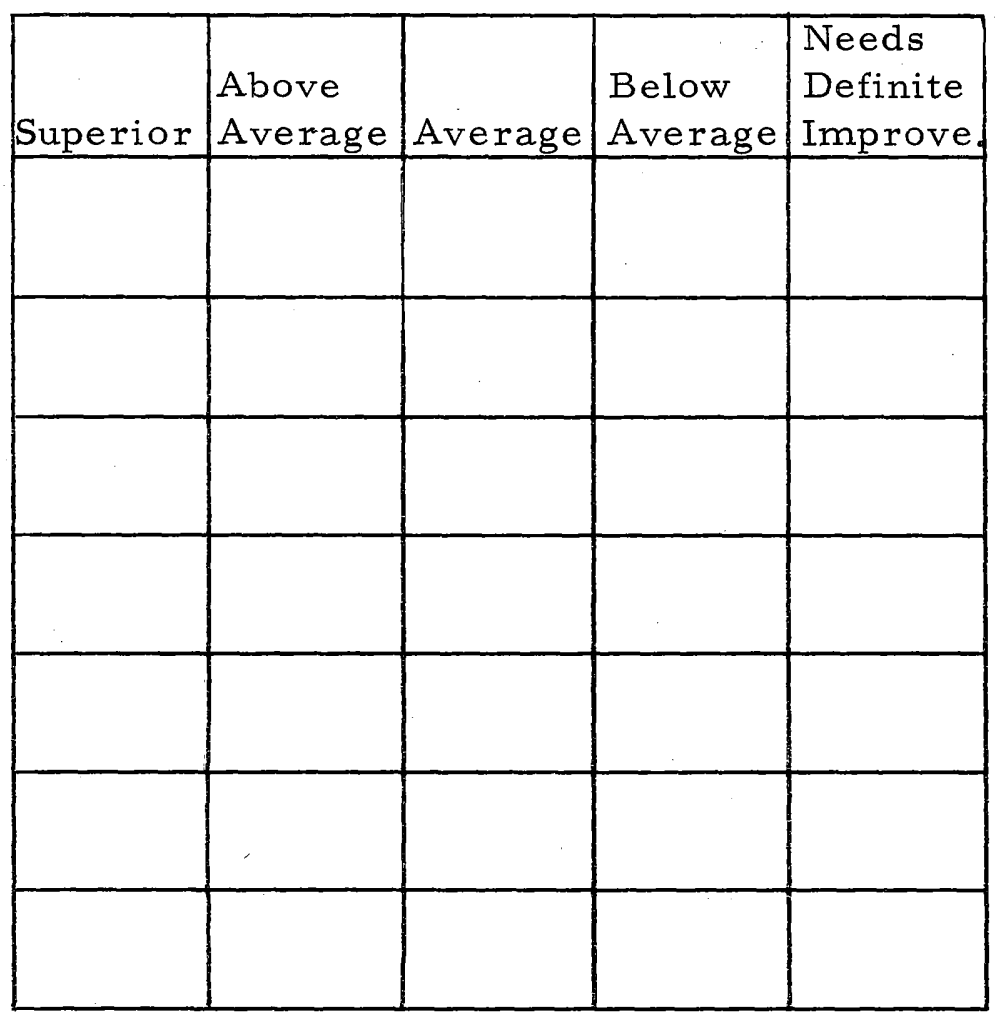

8. Are his skills such that they could qualify him for employment in the regular labor market? YES NO (Circle one). If the answer is yes, indicate possible job areas (i.e. nurse, minister, social worker, etc.) 
APPENDIX D

TEST SCALES

\section{COMMUNITY RESOURCES}

Circle the letter or letters (a, b, $c, d, e)$ in front of the best available resources (one or more) which meet the needs of the clients in the following situations.

1. Working mother needs child care (babysitter).
(a) Neighborhood Service Center
(b) Boys and Girls Aid
(c) Fruit and Flower Nursery Society
(e) Patton Home
(d) Volunteers of America

2. A teen-age girl is pregnant and does not want to keep the baby.
(a) Waverly Children's Home
(b) White Shield Home
(c) Multnomah County Public Welfare
(d) Albertina Kerr Homes

(e) Court of Domestic Relations

3. One of your families is unable to care for an aging relative.
(a) State Board of Health
(b) Legal Aid
(c) Multnomah County Public Welfare
(d) Albertina Kerr Homes

(e) Court of Domestic Relations

4. Mother's drinking problem is causing trouble within the family.
(a) Friendly House
(c) Alcoholic Rehabilitation Clinic
(b) Northwest Towers Center
(e) Alcoholics Anonymous
(d) German Aid Society 
5. A mother doesn't want any more children, where can she go for help?
(a) Legal Aid
(b) Volunteers of America
(c) Planned Parenthood
(e) Family Counseling Service
(d) Multnomah County Health Dept.

6. An 18 year old boy is badly injured in a car accident and is no longer able to work at his old job.
(a) Boys and Girls Aid Society
(c) Crippled Children's Division
(b) Vocational Rehabilita: tion
(e) Multnomah County: Public Welfáre
(d) Oregon State
Employment

7. A family of five children is left in the care of a 17 year old sister after the death of both parents.
(a) Albertina Kerr Homes
(b) Police Department
(c) Edgefield Lodge
(d) Juvenile Court
(e) Welfare

8. A ten year old boy wants to go to summer camp, but the family feels they cannot afford the camp fee.
(a) Salvation Army
(b) Y M C A
(c) Y W C A
(d) Neighborhood House
(e) Jewish Community Center

9. You find a family with nothing in the house to eat and no money.
(a) Family Counseling Service
(b) Life Center
(c) German Aid Society
(d) Welfare
(e) Sunshine Division

10. Where would you send a family who needs help in moving?
(a) Welfare
(c) Neighborhood Service Center
(b) Volunteers of America
(e) Sunshine Division
(d) C-Cap 
11. A mentally retarded child needs play activity with other children.
(a) Kiwanis Camp
(b) Head Start
(c) Volunteers of America
(d) Neighborhood House
(e) Boys and Girls Aid Society

12. An unemployed father wants to find a job.
(a) Neighborhood Service Center
(b) Oregon State
(c) American Red Cross
Employment Service
(e) Family Counseling Service
(d) Salvation Army

13. Father threatens mother and children who are then forced to leave their home, but have no place to go.
(a) Welfare
(c) White Shield Home
(b) Court of Domestic
(e) Neighborhood House Relations
(d) Volunteers of America

14. A father sent home from hospital needs special equipment (hospital bed, wheel chair, etc.).
(a). Welfare
(b) Salvation Army
(c) Vocational Rehabilitation
(d) Easter Seal Foundation
(e) Sunshine Division

15. An elderly person is lonely and has need for social contact.
(a) Friendly House
(c) Neighborhood House
(b) Northwest Towers
(e) Visiting Nurse Association Center
(d) Bureau of Parks

16. Where can an adult who wants to earn a high school diploma go?
(a) Oregon State Employment Service
(b) Division of Continuing Education
(c) Portland Public Schools
(e) Neighborhood Service Center
(d) Vocational Rehabilita- tion

17. Your neighbor's child is continually beaten by his parents.
(a) Boys and Girls Aid Society
(b) Police Department
(c) Visiting Nurse Association
(d) Juvenile Court
(e) Welfare 
18. Family wants help with marital problems.
(a) Court of Domestic Relations
(c) Welfare
(e) Legal Aid

(b) Family Counseling

Service

(d) County Mental Health

Clinic

\section{GENERAL. HEALTH}

Circle the best answer or answers:

1. When a Kaiser doctor sees a case of venereal disease:

a. He refers the person to the Public Health Department for treatment.

b. He refers the person to a private physician.

c. He diagnoses and treats the person keeping in mind confidentiality.

d. He must notify the families of those involved.

e. He emphasizes the need of follow-up treatment.

2. When asked for advice on birth control methods:
a. Tell her to see the doctor.
b. Bear in mind the family's religious affiliation before recom- mending a method.
c. Refer her to the druggist as there are preparations available without prescriptions.
d. Although you may indicate some methods, refer her to her doctor for advice.
e. Discourage giving her advice as statistics show population is declining.

3. When making a home visit, with a mother who has eight children:
a. You should indicate she has too many children to support and needs help with family planning.
b. It is not your business to bring up the subject of family planning unless asked.
c. Refer her to a good book on population explosion.
d. You can inform the mother that family planning information is available.
e. Refer her to her doctor if interested in birth control methods. 
4. A person you talk with is worried about the effects of the medication she is taking:

a. Advise her the doctor is the only one who can help her with this problem.

b. She could talk with the druggist where she bought the medicine and he can suggest an alternate drug.

c. Recommend that she try another type of medication.

d. Advise her to go to the hospital immediately for help.

e. Advise her to discuss this with the doctor the next time she happens to be at the clinic.

5. When a woman becomes pregnant:

a. It is not necessary to see a doctor until the sixth month of pregnancy, because of better health care today.

b. She should watch her diet carefully as this directly affects the unborn baby.

c. Weight control is an important factor in the mother's health.

d. She should visit the doctor regularly.

e. The doctor informs her of post-natal care.

6. Upon making a home visit, you see a child you think has measles:

a. Suggest to the mother that she talk with the doctor over the phone.

b. Suggest that the mother take her child to the clinic for an examination.

c. Indicate that as long as he is feeling all right it is fine for him to play with his friends.

d. Advise her that measles is highly contagious and that he should stay away from his friends.

e. Although you can refer him to the doctor, you should give no medical advice.

7. One of your family members is overweight and asks for help:

a. Suggest the possible use of diet pills as they cut down the appetite.

b. Refer him to the drug store where there are a variety of drugs for this purpose.

c. Give him a diet which you know has been successfully used with others:

d. Suggest that the best person to talk to is his doctor.

e. As a Coordinator you can give no advice on this problem, except where to go for help. 
8. A new mother desires to bottle feed her baby:

a. She should ask her doctor what formula to use.

b. She should take her neighbor's advice as she has raised five children.

c. You should advise her to get free formula at the clinic.

d. It doesn't really matter what formula she uses as there are many similar varieties.

e. You can recommend a number of brand names of formulas, but should encourage the mother to decide with her doctor which one to use.

9. A mother wants help with a feeding problem with her two-yearold boy:

a. This generally means a medical problem and should be discussed right away with the doctor.

b. Advise her that age two is a stubborn age and she should be firmer with him.

c. Advise her to take him to the doctor for a check-up.

d. Reassure her that this is usually normal, but to discuss it with the doctor during her next appointment.

e. Reassure her that this is usually normal, but talk to her doctor and she might get some helpful hints from a babycare book.

10. One of your clients has suffered severe chest and arm pains the night before you see him:

a. You should tell him he might have had a heart attack and should see a doctor as soon as possible.

b. You should encourage him to make an emergency appointment for an examination.

c. You should never mention the relation of the symptoms to heart attack, but refer him to a doctor.

d. Tell him he may have a serious illness and urge him to see a doctor.

e. Don't discuss his symptoms at all, but indicate he should see a doctor that day if possible. 
11. Cigarette smoking is:

a. Less important in the causation of lung cancer than atmospheric pollution. (bad air)

b. Causally related to lung cancer.

c. The most important of the causes of chronic bronchitis.

d. Considered to increase the risk of death from emphysema.

e. Not related to coronary artery disease.

12. Included in the seven danger signals of cancer:
a. Abdominal pain.
b. Unusual bleeding over a long period of time.
c. Swelling in an arm or leg which does not decrease in two weeks.
d. An open sore that refuses to heal.
e. A reduction in hearing.

13. Leukemia:
a. Is a form of blood cancer.
b. Is related to diabetes.
c. Can be cured by drugs.
d. May be partially controlled by medication.
e. May be permanently controlled by medication.

\section{KAISER HEALTH PLAN AND MEDICAL CARE PROGRAM}

\section{Select the Best Answer:}

1. What is meant by "a group medical plan"?

a. A number of insurance companies have gotten together and drawn up a single medical plan to offer people.

b. Doctors have formed a clinic and offer medical care as a team of specialists.

c. A number of people in a company or some other type of group go together in taking out a medical insurance plan.

d. An employer must pay for medical insurance for his employees. 
2. A person who joins a Kaiser plan where he works:

a. Could always have chosen another plan if he'd wanted to.

b. Can always carry the same policy for the same monthly payment after he quits his job.

c. Always has some of his premium paid for by his employer.

d. Pays the same amount for care as he would if he'd joined on his own.

3. The regular Kaiser plan differs from most other medical insurance policies in that:

a. All medical costs are covered by the Kaiser plan while other plans tend to cover only part of the expense.

b. Clinic and laboratory fees are covered by Kaiser whereas they are not in other policies.

c. Kaiser owns and operates the medical facilities the members use and offers its members preventive medical care.

d. Kaiser is a far less expensive program than most medical plans.

4. No Kaiser plan pays anything for:
a. Psychiatric care.
b. Hospitalization for tuberculosis.
c. Treatment for a birth defect.
d. Treatment for attempted suicide.

5. What would make a child ineligible for coverage under the regular Kaiser plan?
a. Reaching age 18 .
b. Being adopted or a foster child.
c. He would be ineligible if his parents' health plan states that there is no coverage for dependents.

d. A child is always covered if he's being supported by his parents and they are members of Kaiser. 
6. Who chooses the people for the OEO Kaiser Program?
a. The Metropolitan Steering Committee.
b. People working on the OEO Project and members of the Medical Care Advisory Committee.
c. The people working on the OEO Project and a group of Kaiser doctors.
d. The Kaiser Health Coordinators.

7. Money for the OEO Kaiser Plan:
a. Is available until the federal government gets around to reviewing how well the program is operating.
b. Could be withdrawn any time if there was a national emergency.
c. Will not be withdrawn without at least a year's notice.
d. Could be withdrawn in June, 1969, as that's the length of time for which funds have been requested.

8. In the first year of the OEO Project which families from the target areas were able to receive services?
a. All families.
b. All poor families.
c. Only selected poor families.
d. All welfare recipients.

9. What besides income level is included in the priorities for accepting an applicant family into the OEO Kaiser Plan?
a. Family size, the presence of medical problems, and the:age of the children.
b. Families with old people are taken first.
c. Welfare recipients get first consideration.
d. Only income level is considered, people are taken in order in which they were contacted.


10. If a person is eligible for the OEO program but hasn't yet been taken on and given an official identification card:

a. He gets treated the same as any OEO member if he needs emergency care.

b. He gets reduced rates at the clinics and hospital.

c. He is given a yearly physical exam without charge to determine whether he meets the requirements of medical need.

d. He will not receive any benefits of the OEO plan until he is taken into the program.

11. If a child of an OEO Kaiser member reaches his 21 st birthday and is a college student:

a. He must be signed up under a separate student health plan because he's no longer a minor.

b. He is eligible for continued coverage until he finishes college.

c. No further benefits are available to him.

d. He can continue under his parent's membership until age 23 so long as he is a member of the household and stays in school.

12. Which statement is the best description of the Health Coordinators' job?

a. The Coordinators help OEO Kaiser members get started in the program and see that they use the program as fully as possible.

b. The Coordinators sign people up for the OEO Kaiser Plan.

c. The Coordinator's job is to drive people to the hospitals and clinics for appointments.

d. Coordinators help participants translate felt needs into needneutralizing services.

13. Which of the following is a true statement about doctors at Kaiser?

a. Doctors work in teams so you never know who you'll get to treat you.

b. Each doctor is a part time physician at Kaiser and handles a private practice the rest of the time.

c. All the doctors are specialists in some field of medicine.

d. Each doctor is a general practitioner and can handle any medical problem that arises with his patients. 
14. Doctors are on duty at all Permanente Clinics:
a. 24 hours a day.
b. From 8 to 10 in the morning and 3 to 5 in the afternoon.
c. From 9:00 AM to 5:00 PM Monday through Saturday.
d. Mondays, Wednesdays and Fridays.

15. A broken leg would be treated by doctors in:
a. Ophthalmology.
b. Obstetrics and gynecology.
c. Orthopedics and surgery.
d. Internal medicine.

16. An eye problem would probably be treated by doctors in:
a. Internal medicine.
b. Urology.
c. Orthopedics and surgery.
d. Ophthalmology.

17. Where is Kaiser Hospital located?
a. It's on Interstate just off Killingsworth.
b. It's between the overpass to Swan Island and Killingsworth Avenue on North Greeley.
c. On Willamette Avenue just south of Killingsworth.
d. It's on North Gantenbein and Commercial.

18. Where are two of the Permanente Clinics located?
a. 77th and Division and 26th and NE Broadway.
b. 6th and NE Broadway and 1 st and SW Thomas.
c. 81 st and Division and 47th and SE Hawthorne.
d. 81 st and Division and 6th and NE Broadway. 
APPENDIX E

PERCENTAGE DISTRIBUTIONS OF SCORES ON RATING QUESTIONNAIRE QUESTIONS BY RANK OF NEIGHBORHOOD HEALTH COORDINATORS

TABLE XIX

QUESTION NUMBER ONE**

\begin{tabular}{|c|c|c|c|}
\hline \multirow{2}{*}{\multicolumn{2}{|c|}{ Rank }} & \multicolumn{2}{|c|}{ Score } \\
\hline & & High & $\overline{\text { Low }}$ \\
\hline \multirow{4}{*}{$\begin{array}{l}\text { High } \\
\text { Low }\end{array}$} & & $70 \%$ & $36 \%$ \\
\hline & & $30 \%$ & $64 \%$ \\
\hline & Total & $\overline{100 \%}$ & $100 \%$ \\
\hline & Number & 10 & 14 \\
\hline object & $\begin{array}{l}\text { e demon } \\
\text { procedu }\end{array}$ & $\begin{array}{l}\text { edge a } \\
\text { ehensi }\end{array}$ & $\begin{array}{l}\text { g of the } \\
\text { ?" }\end{array}$ \\
\hline
\end{tabular}


TABLE XX

QUESTION NUMBER TWO*

\begin{tabular}{|c|c|c|c|}
\hline \multirow[b]{2}{*}{ Rank } & & \multicolumn{2}{|c|}{ Score } \\
\hline & & High & Low \\
\hline High & & $62 \%$ & $36 \%$ \\
\hline \multirow[t]{3}{*}{ Low } & & $38 \%$ & $64 \%$ \\
\hline & Total & $\overline{100 \%}$ & $\overline{100 \%}$ \\
\hline & Number & 13 & 11 \\
\hline
\end{tabular}

TABLE XXI

QUESTION NUMBER THREE*

\begin{tabular}{|c|c|c|c|}
\hline \multirow[b]{2}{*}{ Rank } & & \multicolumn{2}{|c|}{ Score } \\
\hline & & $\overline{\mathrm{High}}$ & Low \\
\hline High & & $70 \%$ & $36 \%$ \\
\hline \multirow[t]{3}{*}{ Low } & & $30 \%$ & $64 \%$ \\
\hline & Total & $\overline{100 \%}$ & $\overline{100} \%$ \\
\hline & Number & 10 & 14 \\
\hline
\end{tabular}


TABLE XXII

QUESTION NUMBER FOUR*

\begin{tabular}{|c|c|c|c|}
\hline \multirow[b]{2}{*}{ Rank } & & \multicolumn{2}{|c|}{ Score } \\
\hline & & $\overline{\text { High }}$ & Low \\
\hline $\mathrm{High}$ & & $64 \%$ & $38 \%$ \\
\hline \multirow[t]{3}{*}{ Low } & & $36 \%$ & $62 \%$ \\
\hline & Total & $\overline{100 \%}$ & $\overline{100 \%}$ \\
\hline & Number & 11 & 13 \\
\hline
\end{tabular}

TABLE XXIII

QUESTION NUMBER FIVE*

\begin{tabular}{|c|c|c|c|}
\hline \multirow[b]{2}{*}{ Rank } & & \multicolumn{2}{|c|}{ Score } \\
\hline & & High & Low \\
\hline High & & $73 \%$ & $31 \%$ \\
\hline \multirow[t]{3}{*}{ Low } & & $27 \%$ & $69 \%$ \\
\hline & Total & $100 \%$ & $\overline{100 \%}$ \\
\hline & Number & 11 & 13 \\
\hline
\end{tabular}

*"To what degree has she benefited from the orientation training in self-awareness?" 
TABLE XXIV

QUESTION NUMBER SIX*

\begin{tabular}{|c|c|c|c|}
\hline \multirow{2}{*}{\multicolumn{2}{|c|}{ Rank }} & \multicolumn{2}{|c|}{ Score } \\
\hline & & $\overline{\mathrm{High}}$ & Low \\
\hline \multicolumn{2}{|l|}{ High } & $100 \%$ & $14 \%$ \\
\hline \multirow[t]{3}{*}{ Low } & & $0 \%$ & $86 \%$ \\
\hline & Total & $\overline{100 \%}$ & $\overline{100 \%}$ \\
\hline & Number & 10 & 14 \\
\hline hood & $\begin{array}{l}1 \text { does } \\
\text { ordinato }\end{array}$ & teract & Neight \\
\hline
\end{tabular}

TABLE XXV

QUESTION NUMBER SEVEN*

\begin{tabular}{|c|c|c|c|}
\hline \multirow{2}{*}{\multicolumn{2}{|c|}{ Rank }} & \multicolumn{2}{|c|}{ Score } \\
\hline & & High & Low \\
\hline \multirow{4}{*}{$\begin{array}{l}\text { High } \\
\text { Low }\end{array}$} & & $71 \%$ & $20 \%$ \\
\hline & & $29 \%$ & $80 \%$ \\
\hline & Total & $\overline{100} \%$ & $\overline{100} \%$ \\
\hline & Number & 14 & 10 \\
\hline Neigh & $\begin{array}{l}\text { your pe } \\
\text { lealth C }\end{array}$ & 11 eva & \\
\hline
\end{tabular}

